九州大学学術情報リポジトリ

Kyushu University Institutional Repository

\title{
Crabs from the East China Sea. IV : Gymnopleura, Dromiacea and 0xystomata
}

Takeda, Masatsune

Zoological Laboratory, Department of Agriculture, Kyushu University

Miyake, Sadayoshi

Zoological Laboratory, Department of Agriculture, Kyushu University

https://doi.org/10.5109/22804

出版情報: 九州大学大学院農学研究院紀要. 16 (3)，pp. 193-235，1970-09. Kyushu University バージョン：

権利関係 : 
Journal of the Faculty of Agriculture, Kyushu University, Vol. 16, No. 3 September 20, 1970

\author{
Crabs from the East China Sea. IV \\ Gymnopleura, Dromiacea and Oxystomata ${ }^{1)}$ \\ Masatsune TAKEDA and Sadayoshi MIYAKE
}

The present paper deals with altogether thirty-two species, of which three are referable to the section Gymnopleura, six to the section Dromiacea and remaining twenty-three to the section Oxystomata. The species dealt herewith are as follows.

Section Gymnopleura

Family Raninidae

Lyreidus integer Terazaki, 1902

Cosmonotus grayii White, 1847

Cosmonotus genkaiae sp. nov.

Section Dromiacea

Family Dromiidae

Cryptodromia areolata Ihle, 1913

Petalomera japonica (Henderson, 1888)

Petalomera yamashitai sp. nov.

Family Tymolidae

Tymolus japonicus Stimpson, 1858

Tymolus uncifer (Ortmann, 1892)

Family Thelxiopidae

Latreillopsis bispinosa Henderson, 1888

Section Oxystomata

Family Dorippidae

Paradorippe granulata (de Haan, 1841)

Ethusa quadrata Sakai, 1937

Ethusa minuta Sakai, 1937

Family Leucosiidae

Ebalia tuberculosa (A. Milne Edwards, 1873)

Ebalia longimana Ortmann, 1892

Ebalia scabriuscula Ortmann, 1892

1) Contributions from the Zoological Laboratory, Faculty of Agriculture, Kyushu

University, No. 429. 
Merocryptus lambriformis A. Milne Edwards, 1873

Praebebalia longidactyla Yokoya, 1933

Actaeomorpha morum Alcock, 1896

Nursia rhomboidalis (Miers, 1879)

Nursia japonica Sakai, 1935

Nursilia dentata Bell, 1855

Arcania undecimspinosa de Haan, 1841

Arcania globata Stimpson, 1858

Randallia eburnea Alcock, 1896

Myra fugax (Fabricius, 1798)

Pariphiculus coronatus (Alcock et Anderson, 1894)

Ixoides cornutus MacGilchrist, 1905

Cryptocnemus obolus Ortmann, 1892

Leucosia obtusifrons de Haan, 1841

Leucosia unidentata de Haan, 1841

Philyra heterograna Ortmann, 1892

Family Calappidae

Matuta curtispina Sakai, 1961

Some systematic and geographical notes are inserted herein.

1) Family Raninidae

It is remarkable that a new species of the genus Cosmonotus which has hitherto been known only by an unique species is described from the East China Sea and the north of Kyushu. The early known species, C. grayii, bears a wide distribution in the Indo-West Pacific waters from Japan to Western Australia, and to the Red Sea and Natal, South Africa, but the geographical range may be possibly corrected after examination of many specimens from the various localities. It is noted that the paratypic specimen of the new species was obtained from the stomach of a flounder, Pseudorhombus cinnamoneus (Temminck et Schlegel).

2) Family Dromiidae

In the collection are comprised only three species, one of which is described as new to science. The genera Petalomera and Cryptodromia are at present separated only by bearing or not the epipod on the coxa of the cheliped. The new species is referable to the genus Petalomera on account of bearing the epipod on the coxa of the cheliped, but the meri of the chelipeds and ambulatory legs are not petaloid unlike in the cases of the typical species. As regards the geographical distribution, the other two species are restricted to the West Pacific, viz. $C$. areolata from Japan and Timor Island, and $P$. japonica from Japan and North China. Both species are not uncommon in the Japanese waters along the Pacific coast. 


\section{3) Family Tymolidae}

As discussed in detail by Gordon (1963), the systematic status of a small group of crabs that has been dealt with as a subfamily of the family Dorippidae is still now unsettled. At present the family is tentatively included in the section Dromiacea, not in Oxystomata. $\Lambda \mathrm{s}$ already pointed also by Gordon, the "peditremen" forms with genital opening coxal in the female among the Brachyura are the Dromiacea, the Raninidae and the Tymolinae, all the rest being "sternitremen" with the female genital opening sternal. Gordon (1963) remarked as, "Certainly the so-called Tymolinae with sternal furrows and coxal genital pores should not be placed in the same family as the dorippids without sternal furrows and with the genital openings of the female sternal. The tymolids should at least be placed in a separate family, Tymolidae; their true place in the classification is with or near the Dromiacea."

4) Family Thelxiopidae

$\Lambda$ mong the crabs from the East China Sea, only a representative of the genus Latreillopsis, L. bispinosa, is recorded. Some of the members of the genus Latreillopsis are not distinctly separated from the genus Paromola Alcock et Anderson, e.g. L. petterdi Grant. As discussed by Gordon (1950) both genera are possibly distinguished from each other most readily based on the branchial formulae. L. bispinosa is a type-species of the genus and bears a wide distribution in the IndoWest Pacific waters.

5) Family Dorippidae

The distribution of Paradorippe granulata is rather northern, ranging from Vladivostok southwards to Hongkong, while the two species of the genus Ethusa are restricted to the Japanese waters. E. minuta is very variable in the granulation and hairiness of the carapace, so that the discrimination of the species from $E$. izuensis Sakai is sometimes diffcult. The formation of the spout is, however, always different from each other in both species.

6) Family Leucosiidae

The genus Ebalia is apparently heterogenerous and should be more subdivided. Among the members referred to the genus at present, the general formation of the carapaces is rather alike each other, but the segmentation of the abdomens in the males and in the females, and also the lengths of the second male pleopods are variable. Of the species dealt herewith Ebalia scabriuscula bears the abdominal formula of the male being $1+2+R+6+T$, the abdominal formula of the female 
being $1+2+3+R+T$, and the short second male pleopod, while in $E$. longimana the abdominal formula is $1+2+R+T$ in the male, $1+2+R+T$ in the female, and the second male pleopod is much longer than the first. In the latter species the abdominal formula and the long second pleopod seem to coincide with those of the genus Philyxia Bell which is usually eliminated or ranked to a subgenus. In the group of the species referable to Philyxia, however, the abdominal formulae of the females are not always constant. At present, with regards those features the knowledge is by no means exhaustive, so that the three species from the East China Sea are tentatively assigned to the genus Ebalia ac. cording to precedent. The monographical treatment based on many species are very desirable.

All the species dealt herewith have already known from the Japanese waters, but the descriptions and figures are given to the three imperfectly known species, viz. Praebebalia longidactyla, Nursia rhomboidalis and Nursilia dentata. Most of the twenty-three species dealt herewith are rather widely distributed in the Indo-West Pacific waters, but Ebalia scabriuscula, Ebalia longimana, Praebebalia longidactyla, Nursia japonica and Nursia rhomboidalis are restricted to the Japanese waters. The West Pacific species known from the Japanese waters and some additional localities are Arcania globata, Cryptocnemus obolus and Philyra heterograna, while the remaining species are also known from the Indian Ocean. It is peculiar that Merocryptus lambriformis also occurs in New Zealand, and that Myra fugax extends the range to the east Mediterranean through the Suez Canal.

\section{7) Family Calappidae}

In the collection is Matuta curtispina which was recently described from Sagami Bay and off Aichi Prefecture. Only a specimen available is young, but well agreeable with the original description and also with the specimens from Ise Bay. Therefore, the species extends the geographical range southwards to the East China Sea and the bathymetric range down to $111 \mathrm{~m}$.

The materials examined are preserved in the Zoological Laboratory, Kyushu University (ZLKU) with an exception of the holotype of Cosmonotus genkaiae sp. nov. which should be deposited in the National Science Museum, Tokyo.

Family Raninidae

Genus Lyreidus de Haan, 1841

Lyreidus integer Terazaki, 1902 
Lyreidus integra Terazaki, 1902, p. 217, 1 fig.-Sagami Sea, $270 \mathrm{~m}$ deop.

Lyreidus politus Parisi, 1914, p. 311, pl. 13, fig. 5-Sagami Bay.

Lyreidus politus, Gordon, 1931, p. 523-Hongkong.

Lyreidus integra, Shen, 1931, p. 190, fig. 7, pl. 12, fig. 2-Hongkong.

Lyreidus politus, Yokoya, 1933, p. 112-West of Kagoshima Pref., $88 \mathrm{~m}$ deep.

Lyreidus politus, Sakai, 1934, p. 283, pl. 18, fig. 5-Sagami Bay, Shimoda and Kii.

Lyreidus politus, Sakai, 1936, p. 68, pl. 13, fig. 4-Japan.

Lyreidus politus, Sakai, 1937, p. 172, fig. 43-Tosa Bay.

Lyreidus integra, Sakai, 1965, p. 5, pl. 2, fig. 2-Sagami Bay, 80-120 m deep.

Material examined.

Off Chilung, Taiwan; 10 , ZLKU No. 13356; November 1966; Taiwan Mar. Res. Inst. leg., received through Mr. H. P. Yu.

Measurements.

$\sigma^{t}$ (No. 13356): Length of carapace, $46.6 \mathrm{~mm}$; breadth of carapace, 25.5 mm.

Distribution. This species is known from Japan and Hongkong. In the Japanese waters it ranges from Sagami Bay through the Kii Province, Tosa Bay and the west of Kagoshima Prefecture southwards to the north of Taiwan as reported at present. Its bathymetric range is 80 to $270 \mathrm{~m}$.

\section{Genus Cosmonotus White, 1847 \\ Cosmonotus grayii White, 1847 \\ (Figs, 1, A, 2, G-I, and 3, C, D)}

Cosmonotus Grayii, White, 1847, p. 129 (descriptio nulla)-Borneo.

Cosmonotus Grayii, White, $1847 \mathrm{a}$, p. 227, 2 figs.-No new locality.

Cosmonotus Grayit, White, 1848, p. 287, 2 figs.-No new locality.

Cosmonotus Grayii, Adams and White, 1848, p. 60, pl. 13, fig. 3-No new locality.

Cosmonotus grayii, Henderson, 1888, p. 33-Amboina, $30 \mathrm{~m}$ deep.

Cosmonotus grayii, Alcock, 1896, p. 292-Persian Gulf.

Cosmonotus Grayi, Doflein, 1904, p. 51, pl. 18, figs. 5-8-Dar es Salaam, $50 \mathrm{~m}$ deep.

Cosmonotus Grayil, Stimpson, 1907, p. 181-North of Taiwan, $160 \mathrm{~m}$ deep.

Cosmonotus Grayl, Balss, 1915, p. 16-Red Sea, $212 \mathrm{~m}$ deep.

Cosmonotus grayi, Ihle, 1918, p. 294-Molo Str., 69-91 m deep.

Cosmonotus grayti, Stebbing, 1920, p. 250-Natal, $100 \mathrm{~m}$ deep.

Cosmonotus grayii, Yokoya, 1933, p. 113-Many localities from Sagami Bay to Kagoshima along Pacific coast, and from Goto Is. to off Shimane Pref., Sea of Japan, 75-132 m deep.

Cosmonotus grayi, Sakai, 1936, p. 66, pl. 13, fig. 3-Japan.

Cosmonotus grayii, Sakai, 1937, p. 173, pl. 16, fig. 2-Sagami Bay. 
Cosmonotus grayi, Stephensen, 1945, p. 96-No new locality.

Cosmonotus grayii, Barnard, 1950, p. 400, fig. 75, h, i-No new locality.

Cosmonotus grayi, Tyndale-Biscoe and George, 1962, p. 90, fig. 8, off Onslow, W. Aust., 35 and $95 \mathrm{~m}$ deep.

Cosmonotus grayi, Sakai, 1965, p. 4, p1. 1, fig. 5-Sagami Bay, 80-95 m deep. Material examined.

$27^{\circ} 55^{\prime} \mathrm{N}, 123^{\circ} 35^{\prime} \mathrm{E} ; 1$ \% , ZLKU No. 13424 ; April 9, 1962 ; H. Yamashita leg.

Measurements.

우 (No. 13424): Greatest length of carapace, $7.0 \mathrm{~mm}$; length of carapace in median line, $6.7 \mathrm{~mm}$; breadth of carapace, $5.9 \mathrm{~mm}$.

Remarks. As regards the nomenclature concerned with the priority, it is noted that the genus Cosmonotus and the species $C$. grayii should be dedicated to White, 1847, not to Adams et White, 1848. Though those names dedicated to Adams et White were first appeared in List of the specimens of Crustacea in the collection of the British Museum (1847), it should be generally regarded to be nomen nudum. The full description with fine figures of the present species was given by White (1847a) prior to the appearance of the report on the Crustacea of H.M.S. Samarang.

Distribution. This species is widely-distributed in the Indo-West Pacific waters from Japan to Western Australia and to the east coast of Africa and the Red Sea. In the Japanese waters it ranges from Sagami Bay southwards to the north of Taiwan along the Pacific coast and from the Goto Islands northwards to off Shimane Prefecture, the Sea of Japan. Its bathymetric range is from 30 to $212 \mathrm{~m}$.
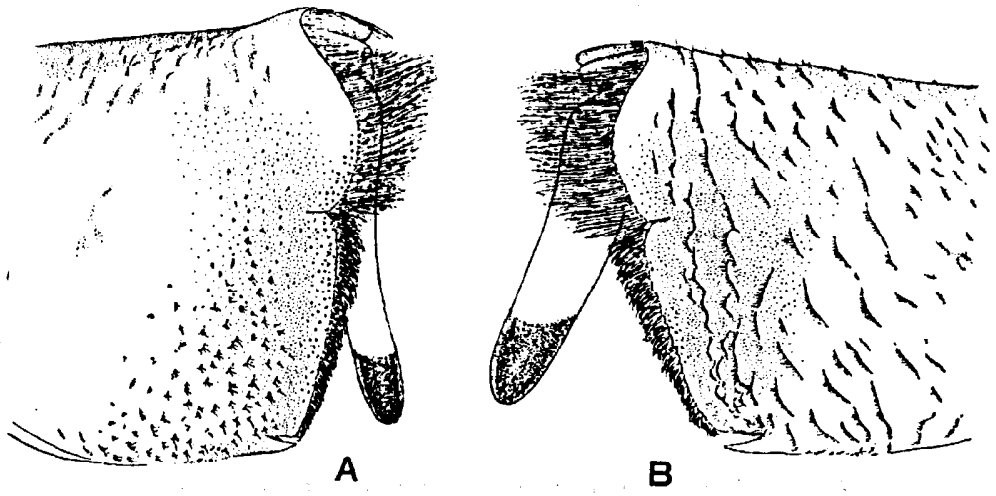

B

Fig. 1. Cosmonotus grayii White, $\delta^{7}(7.4 \times 6.2 \mathrm{~mm})$ from east of Tsushima I. A, anterior right half of carapace in lateral view. Cosmonotus genkaiae sp. nov., holotype, $\sigma^{\lambda}(7.1 \times 5.8 \mathrm{~mm})$ from east of Tsu-shima I. B, anterior left half of carapace in lateral view. 
Cosmonotus genkaiae sp. nov.

(Figs. 1, B, 2, A-F and 3, A, B)

Description of holotype. The carapace is strongly compressed, especially so anteriorly, the summit forming a weak median ridge. The anterior

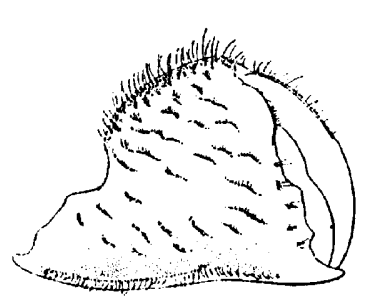

B

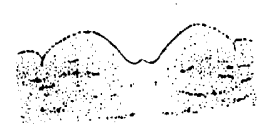

A
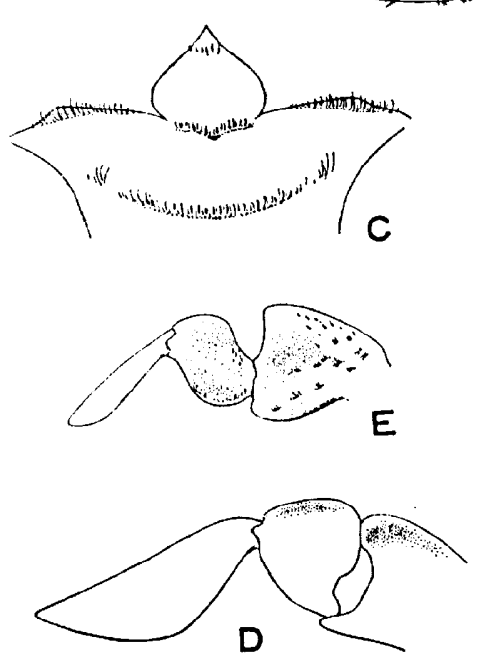

Fig. 2. Cosmonotus genkaiae sp. nov., holotype, $\delta(7.1 \times 5.8 \mathrm{~mm}), \mathrm{A}-\mathrm{F}$. Cosmonotus grayii White, $3(7.4 \times 6.2 \mathrm{~mm}), \mathrm{G}-\mathrm{L}$.

$A, G$, median frontal region in dorsal view, $\times 7.5 ; B, H$, right chela in outer view, $\times 10 ; C, I$, anterior part of thoracic sternum, $\times 17.5$; D, distal three segments of left first ambulatory leg, hairs omitted, $\times 12.5$; J, distal three segments of left third ambulatory leg, $\times 10 ; \mathrm{E}, \mathrm{K}$, distal three segments of left fourth leg, $\times 10$; F, L, abdomen, hairs omitted, $\times 12.5$ and 10 . 
half of the surface is ornamented with shallow longish depression fringed each with a row of short hairs; those depressions are more prominent and more or less squamiform towards the supraorbital borders and the antero-external angles. The front is excised in V-shaped sinus, being filled by the basal segments of the eyestalks; however, in reality, there is a small, acute median process. The eyestalks are of remarkable lengths, rather stout and occupy the whole anterior borders of the carapace; the supraorbital border is prominently spinulated. Behind the external orbital angle is a slender spine that is directed forwards and weakly curved inwards near the tip.

The chelipeds are heavy and granulated; the granules are mostly beaded to form short rows fringed with longish simple hairs, being more or less squamiform; at the upper distal extremity of the carpus is a stout tubercle. The palm is strongly compressed and sparsely provided with the granulated and hairy ridges of various lengths; both the upper and the lower borders are crested and fringed each with a row of longish hairs. The immovable finger is very short, but the distal edge of the palm is so dentated that as a whole the cutting edge is long; the movable finger is very vertical on account of the short immovable finger, and bears a low blunt tooth at the middle.

The ambulatory legs are hairy, and the last pair is most prominently bordered with long plumose hairs. The dactyli of the first and third ambulatory legs are rather distinctly foliaceous, and that of the first one is more or less curved. The third ambulatory legs are missing. In the last leg the coxa is markedly large, and the ischium is only slightly shorter than the merus.

The abdomen is composed of seven segments, and in the second to sixth segments each of the posterolateral angles is produced and more or less overhangs the next segment.

\section{Material examined.}

$34^{\circ} 25.1^{\prime} \mathrm{N}, 129^{\circ} 59.3^{\prime} \mathrm{E}$ (St. 35), $115 \mathrm{~m}$ deep, coarse sand and shells; $1 \sigma^{\prime}$ (holotype), ZLKU No. 12690; August 5, 1968 ; Tsu-shima I. Exp. leg.

East China Sea without definite locality; 1 iq (paratype) from stomach of fish, Pseudorhombus cinnamoneus (Temminck et Schlegel), ZLKU No. 940; July 1954; H. Maéda leg.

\section{Measurements.}

Holotype, $\sigma^{\prime}$ (No. 12690): Greatest length of carapace, $7.1 \mathrm{~mm}$; length of carapace in median line, $6.9 \mathrm{~mm}$; breadth of carapace, $5.8 \mathrm{~mm}$.

Paratype, + (No. 940): Greatest length of carapace, $10.1 \mathrm{~mm}$; length of carapace in median line, $9.4 \mathrm{~mm}$; breadth of carapace, $7.0 \mathrm{~mm}$.

Remarks. This species is apparently close to $C$. grayii White, the 
unique species of the genus. The following important differences between the two species are, however, most readily enumerated. (1) In this species the dorsal surface of the carapace is not ornamented with granulated short, hairy ridges, but with longish hairy depressions and ridges. The carapace is therefore rather distinctly squamose in its appearance. (2) The V-shaped incision of the front is provided with a median minute process. (3) The eyestalks of this species are much more stouter than those of $C$. grayii. (4) The anterior process of the thoracic sternum is somewhat triangular in this species, and more or less quadrate in $C$. grayii. (5) The lower border of the palm is fringed with a row of hairs in this species, while in C. grayii it is provided with many, oblique short rows of hairs. (6) In this species the dactyli of the first three pairs of the ambulatory legs are more strongly foliaceous, so that they are rather distinctly trigonal. In the last leg of $C$. grayii the carpus is distinctly crested along the posterior border, and covered with many granules fringed with one or two hairs. In this species the crest is very low, and the short rows of hairy ridges are rather sparse. (7) The first male pleopod of this species is more incomplete than that of $C$. grayii, and in the second one the distal beak is much more shorter.



Fig. 3. Cosmonotus genkaiae sp. nov., holotype, $\sigma^{7}(7.1 \times 5.8), A, B$. Cosmonotus grayii White, $\sigma^{-1}(5.5 \times 4.5 \mathrm{~mm})$ from east of Tsushima I., C, D.

A, C, left first pleopod, $\times 40 ; B, D$, left second pleopod, $\times 40$.

In addition to the type-specimens, at present in the Zoological La- 
boratory, Kyushu University is one male collected by S.S. Soyo-Maru from the station 465, the north of the Goto Islands, the west of Hirato, $106 \mathrm{~m}$ deep, and reported by Yokoya (1933) as C. grayii. The specimen is in a bad state of preservation, being damaged at the frontal region and the abdominal part. All the ambulatory legs and the chelipeds but the left chela are missing, but the ornamentation of the dorsal surface of the carapace is very well agreeable with that of the holotype.

The present species is named for the research vessel 'Genkai' by which the holotype was collected for the trustees of the National Science Museum, Tokyo.

\section{Family Dromiidae Genus Cryptodromia Stimpson, 1858 \\ Cryptodromia areolata Ihle, 1913}

Cryptodromia areolata Ihle, 1913, p. 47, pl. 2, figs. 10, 11-Timor I., $112 \mathrm{~m}$ deep.

Cryptodromia Ihlei Balss, 1921, p. 177-Sagami Bay and Uraga Str., 130-150 m deep. Cryptodromia Ihlei, Balss, 1922, p. 107, fig. 2-No new locality.

Cryptodromia ihlei, Yokoya, 1933, p. 98-Tosa Bay, Bungo Str., off Miyazaki Pref. and Amakusa Sea, 97-119 m deep.

Cryptodromia areolata, Sakai, 1936a, p. 26, pl. 1, fig. 1-Sagami Bay.

Cryptodromia areolata, Miyake, 1961, p. 13-Amakusa Sea.

Cryptodromia areolata, Sakai, 1965, p. 8, pl. 3, fig. 4-Sagami Bay, 30-120 m deep.

Material examined.

$27^{\circ} 14.5^{\prime} \mathrm{N}, 124^{\circ} 45^{\prime} \mathrm{E} ; 1 \sigma^{\circ}$, ZLKU No. 13425; June 12, $1962 ;$ H. Yamashita leg.

$28^{\circ} 44.7^{\prime} \mathrm{N}, 124^{\circ} 51.7^{\prime} \mathrm{E}, 92 \mathrm{~m}$ deep; 1 ovig. 오, ZLKU No. 13426 ; June 13, $1963 ; \mathrm{H}$. Yamashita leg.

$29^{\circ} 30.7^{\prime} \mathrm{N}, 126^{\circ} 31^{\prime}$ E, $100 \mathrm{~m}$ deep; 1 오, ZLKU No. 13427 ; June 27, 1962 ; H. Yamashita leg.

$30^{\circ} 15.2^{\prime} \mathrm{N}, 127^{\circ} 26.4^{\prime}$ E, $121 \mathrm{~m}$ deep; 1 ㅇ, ZLKU No. 13428 ; June 11, 1963 ; H. Yamashita leg.


Yamashita leg.

$32^{\circ} 0.6^{\prime} \mathrm{N}, 127^{\circ} 12^{\prime}$ E, $120 \mathrm{~m}$ deep; $1 \precsim$, ZLKU No. 13435 ; June 17, 1964 ; H. Yamashita leg.

Measurements.

$\sigma \sigma^{7}$ (No. 13425 and 13435): Length of carapace including frontal lateral teeth, 6.8 and $6.4 \mathrm{~mm}$; breadth of carapace, 6.8 and $6.1 \mathrm{~mm}$.

Ovig. ㅇ (No. 13426): Length of carapace including frontal lateral teeth, $6.3 \mathrm{~mm}$; breadth of carapace, $6.1 \mathrm{~mm}$.

우우 (No. 13429-4 and 13427): Length of carapace including frontal lat- 
eral teeth, 9.0 and $8.0 \mathrm{~mm}$; breadth of carapace, 8.9 and $7.9 \mathrm{~mm}$.

Distribution. This species is known only from Timor Island and Japan. In the Japanese waters it is rather commonly found from Sagami Bay southwards to the west of Kyushu and also to the East China Sea as reported at present. Its bathymetric range is from 30 to $150 \mathrm{~m}$.

\section{Genus Petalomera Stimpson, 1858 \\ Petalomera japonica (Henderson, 1888)}

Cryptodromia japonica Henderson, 1888, p. 6, pl. 1, fig. 2-Tokyo Bay, 10-35 m deep. Cryptodromia canaliculata var. ophryoessa Ortmann, 1892, p. 545-Tokyo Bay.

Cryptodromia asiatica Parisi, 1915, p. 105, pl. 2, fig. 3-Tokyo Bay.

Paradromia japonica, Balss, 1922, p. 108, figs. 3, 4-Tokyo Bay and Sagami Bay, $150 \mathrm{~m}$ deep.

Petalomera granulata, Shen, 1932, p. 3, figs. 1-3, pl. 1, figs. 9, 10-Peichihli Bay and Shantung Penin., North China.

Paradromia japonica, Sakai, 1934, p. 282-Nagasaki.

Paradromia japonica, Sakai, 1936, p. 32, figs. 1, 2-Japan.

Petalomera japonica, Sakai, 1936a, p. 36, pl. 8, fig. 1-Iwate Pref. and Tateyama Bay. Petalomera japonica, Miyake, 1961, p. 13-Amakusa Sea.

Petalomera japonica, Miyake, 1961a, p. 169-Sea of Ariaké.

Petalomera japonica, Sakai, 1965, p. 10, pl. 4, fig. 3-Sagami Bay, 10-20 m deep.

Material examined.

$27^{\circ} 14.5^{\prime} \mathrm{N}, 124^{\circ} 45^{\prime} \mathrm{E} ; 1^{\Im}$, young, ZLKU No. 13436 ; June 12,1962 ; H. Yamashita leg. $28^{\circ} 32^{\prime} \mathrm{N}, 126^{\circ} 18.8^{\prime} \mathrm{E}$; 2 ớ, young, ZLKU No. 13437 ; June 13, 1962 ; H. Yamashita leg.

\section{Measurements.}

$\sigma^{7}{ }^{7}$ (No. 13436 and 13437-1): Length of carapace including frontal lateral teeth, 6.4 and $5.0 \mathrm{~mm}$; breadth of carapace, 6.3 and $4.6 \mathrm{~mm}$.

Distribution. This species occurs in Japan, the East China Sea and North China. In Japan it ranges from the coast of Iwate Prefecture southwards to the west of Kyushu along the Pacific coast. Its bathymetric range is from 10 to $150 \mathrm{~m}$.

Petalomera yamashitai sp. nov. (P1. 1, Figs. A, B)

Description of holotype. The carapace is not markedly convex, but rather evenly in both directions; its dorsal surface is entirely covered with thick, short and stiff setae that are densely provided with micro- 
scopical secondary hairs; on the greater dorsal surface the setae are very short and felt-like, but near the frontal and lateral borders they become longer and disguise the true borders; on denudation, the surface is quite smooth and ill-defined only with very shallow cervical groove. The frontal median tooth is acuminate at the tip and almost perpendicularly directed downwards, being only slightly visible in dorsal view; each of the frontal lateral teeth is as large as the median one, and is not tuberculate but subacute, bearing a broad base. The preorbital angle is more or less produced to be a low tooth with a conical granules of good size; it is united with the frontal lateral tooth to form an imperfect, thick bordered preorbital eave that is weakly convex dorsally. The supraorbital border is indistinctly demarcated from the dorsal surface of the carapace, and dorsally concave near the preorbital angle. The external orbital angle is not prominent, forming only a part of the orbital border. The distance between the preorbital and external orbital angles is considerably longer than the length of the preorbital eave, which is as long as the distance between the frontal lateral teeth. The infraorbital border bears a deep notch just below the external orbital angle and one near its inner extremity; the infraorbital border is produced into a more or less angulated prominence outside the notch near its inner extremity. The orbit is deep. long and oblique, so that the eyestalk and cornea are entirely retreated into the orbit, and the fronto-orbital border is only slightly shorter than the greatest breadth of the carapace.

The lateral border of the carapace is not convex, but nearly parallel or only slightly convergent; each of the borders is separated into the anterolateral and posterolateral parts by a posterior cervical groove; the anterolateral part is armed with two teeth behind the external orbital angle; each tooth bears the tip with a conical granule of good size at its anterior end, and weakly convex at its outer border; the second tooth is slightly longer than the first; just behind and somewhat below the posterior end of the second tooth is a cervical indentation which is continuous with the epimeral ridge; the posterolateral part is unarmed and about half the length of the anterolateral. The epimeron is imperfectly indurated.

The right cheliped is not markedly stout, unfortunately the left being missing. The outer surfaces of the merus, carpus and palm are densely covered with the same hairs as on the carapace. The upper border of the merus is not crested but rather sharp, being fringed with longer setae and a row of conical granules; the outer and inner surfaces of the merus is entirely flattened. The carpus is armed with two tubercles, viz. the larger one at the median distal part and the junction with the palm, and the smaller one at the antero-outer angle. 
There are three pearly granules on the upper border of the palm, and also some near the lower border. The outer surface of the movable finger is for its greater part shallowly but distinctly excavated and provided with setae; the immovable finger is also covered with dense setae; each of the cutting edges bears several teeth which become larger near the tip of the finger; when the fingers are closed, a very narrow gape is left proximally, and the teeth are well interlocked distally.

The ambulatory legs are covered with setae like the carapace and chelipeds, being fringed with longer ones. In the first two pairs the upper border of each merus is armed with a row of conical granules; in the carpus each of the distal extremities of both borders is distinct as a lobe, but not tuberculated; the lower border of the dactylus bears five yellowish, semitransparent spinules. In the last two pairs the fourth is apparently longer than the preceding; each of the dactyli is strongly curved and chelate together with two spines of the propodus; in addition, the propodus bears two spines opposite side of chela in the third leg, and three in the last leg; otherwise, the curved dactylus of the last leg is provided with an accessory spine at its proximal dorsal part; all the accessory spines as well as the dactylus are yellowish and semitransparent at their distal halves.

\section{Material examined.}

$32^{\circ} 24.8^{\prime} \mathrm{N}, 129^{\circ} 24.7^{\prime} \mathrm{E} ; 2$ ovig. 우우 (holotype and paratype), ZLKU No, 13439 and 13440 ; October 24, 1962 ; H. Yamashita leg.

\section{Measurements.}

Holotype, ovig. P (No. 13439): Length of carapace including frontal lateral teeth, $9.5 \mathrm{~mm}$; breadth of carapace, $9.6 \mathrm{~mm}$.

Paratype, ovig. + (No. 13440): Length of carapace including frontal lateral teeth, $9.6 \mathrm{~mm}$; breadth of carapace, $9.5 \mathrm{~mm}$.

Remarks. In the paratype the ornamentation of the carapace and the armatures of the ambulatory legs are very well agreeable with those of the holotype, but unfortunately both chelipeds are missing.

On account of bearing the smooth carapace and two anterolateral teeth, this species is the nearest kin of $P$. lateralis (Gray). In the Zoological Laboratory, Kyushu University is a large male from New South Wales kindly sent by late Mr. M. Ward of the Australien Museum. In $P$. lateralis the carapace is wider than long, the frontal median tooth is horizontal, the subhepatic tooth is prominent, the posterolateral border of the carapace is tuberculated just behind the cervical indentation, and the chelipeds and first two ambulatory legs are prom- 
inently tuberculated.

This species is named in honour of $\mathrm{Mr}$. H. Yamashita who kindly presented many specimens from the East China Sea to the Zoological Laboratory, Kyushu University.

\section{Family Tymolidae \\ Genus Tymolus Stimpson, 1858 \\ Tymolus japonicus Stimpson, 1858}

Tymolus japonicus, Stimpson, 1858, p. 163-Hakodate Bay, $15 \mathrm{~m}$ deep.

Cyclodorippe dromioides Ortmann, 1892 , p. 559, pl. 26, fig. 5-Sagami Bay, Kadsiyama (=Katsuyama) and Wakasa Bay, 65-180 m deep.

Cyclodorippe dromioides, Doflein, 1904, pl. 12, fig. 8.

Tymolus japonicus, Stimpson, 1907, p. 169, pl. 19, fig. 3-No new locality.

Cyclodorippe dromioides, Parisi, 1914, p. 299-Tokyo Bay.

Tymolus japonicus, Balss, 1922, p. 116-Sagami Bay and Uraga Str., 80-600 m deep.

Tymolus japonicus, Yokoya, 1933, p. 105-Numerous localities around Japan but Hokkaido, 44-344 $\mathrm{m}$ deep.

Tymolus japonicus, Sakai, 1935, p. 65, fig. 1-Sagami Bay.

Tymolus japonicus, Sakai, 1936, p. 39, fig. 4, pl. 6, fig. 2-Japan.

Tymolus japonicus, Sakai, 1937, p. 69, pl. 10, fig. 3-Sagami Bay and Nagasaki.

Tymolus japonicus, Miyake, 1961, p. 13-No new locality.

Tymolus japonicus, Gordon, 1963, pp. 51-53, figs. 10, A, 11, A-Sagami Bay.

Tymolus japonicus, Sakai, 1965, p. 20, pl. 10, fig. 2-Sagami Bay, 65-85 m deep.

Material examined.

$30^{\circ} 15.2^{\prime} \mathrm{N}, 127^{\circ} 26.4^{\prime} \mathrm{E}, 121 \mathrm{~m}$ deep; $1 \mho^{\wedge}$, ZLKU No. 13441 ; June 11, 1963 ; H. Yamashita leg.

$33^{\circ} 54.8^{\prime} \mathrm{N}, 123^{\circ} 30.4^{\prime} \mathrm{E}, 68 \mathrm{~m}$ deep; 13 , ZLKU No. 13442 ; March 17, $1964 ; \mathrm{H}$. Yamashita leg.

$34^{\circ} \mathrm{N}, 123^{\circ} 58^{\prime} \mathrm{E}, 78 \mathrm{~m}$ deep; 13 , 1 ovig. 우, 1우, ZLKU No. 13445; October 21, 1962 ; H. Yamashita leg.

$34^{\circ} 1^{\prime} \mathrm{N}, 122^{\circ} 30.3^{\prime} \mathrm{E}, 44 \mathrm{~m}$ deep; 1 ovig. 우, ZLKU No. 13446 ; October 16, $1962 ; \mathrm{H}$. Yamashita leg.

Measurements.

$\sigma^{\circ}$ (No. 13441 and 13445-1): Length of carapace, 8.9 and $8.2 \mathrm{~mm}$; breadth of carapace, 9.3 and $8.2 \mathrm{~mm}$.

Ovig. 우우 (No. 13446 and 13445-2): Length of carapace, 7.8 and $7.4 \mathrm{~mm}$; breadth of carapace, 8.1 and $7.8 \mathrm{~mm}$.

우 (No. 13445-3): Length of carapace, $7.8 \mathrm{~mm}$; breadth of carapace, $8.3 \mathrm{~mm}$.

Distribution. This species is restricted to the Japanese waters. It is 
known from Hakodate Bay and the Tsugaru Strait southwards to the west of Kyushu and the East China Sea along both coasts. Its bathymetric range is from 15 to $600 \mathrm{~m}$.

\section{Tymolus uncifer (Ortmann, 1892)}

Cyclodorippe uncifera Ortmann, 1892, p. 560, pl. 26, fig. 6-Sagami Bay, $180-360 \mathrm{~m}$ deep.

Cymonomops glaucomma Alcock, 1894, p. 406-Andaman Sea, $730 \mathrm{~m}$ deep.

Cymonomops glaucomma, Illust. Zool, Invest., Crust., 1896, pl, 14, fig. 9.

Cymonomops glaucomma, Alcock, 1896, p. 287-Andaman Sea, $480 \mathrm{~m}$ deep.

Cyclodorippe uncifera, Doflein, 1902, p. 653-Sagami Bay, $50 \mathrm{~m}$ deep.

Cyclodorippe uncifera, Doflein, 1904, p. 34, pl. 13, figs.4-7, pl. 38, figs. 6, 7-Zanzibar Canal and east coast of Africa, 463 and $638 \mathrm{~m}$ deep.

Cyclodorippe uncifera, Parisi, 1914, p. 297, pl. 13, fig. 2-Tokyo Bay.

Tymolus uncifer, Balss, 1922, p. 116-Sagami Bay, $600 \mathrm{~m}$ deep.

Tymolus uncifer, Yokoya, 1933, p. 103-Numerous localities from south of Shiriyazaki to west of Kyushu, $55-452 \mathrm{~m}$ deep.

Tymolus uncifer, Sakai 1937, p. 70, pl. 10, fig. 2-Fukushima Pref. and Sagami Bay, 60-100 $\mathrm{m}$ deep.

Tymolus uncifer, Sakai, 1965, p. 21, pl. 10, fig. 3-Sagami Bay, 80-160 m deep.

Material examined.

$29^{\circ} 48.5^{\prime} \mathrm{N}, 127^{\circ} 43.7^{\prime}$ E, $434 \mathrm{~m}$ deep ; 1 ovig. 우, 1 우, ZLKU No. 13448 ; December 6, 1967 ; H. Yamashita leg.

\section{Measurements.}

Ovig. of (No. 13448-1): Length of carapace, $5.6 \mathrm{~mm}$; breadth of carapace, $6.0 \mathrm{~mm}$.

우 (No. 13448-2): Length of carapace, $5.9 \mathrm{~mm}$; breadth of carapace, 6.4 $\mathrm{mm}$.

Remarks. Recently several specimens collected by S.S. Soyo-Maru and reported by Yokoya (1933) were re-examined. Of those specimens examined a female from the station 575 , the north of Noto, $123 \mathrm{~m}$ deep is not referable to the present species, but to $T$. japonicus. Therefore, the record of occurrence in the Sea of Japan should be eliminated.

Distribution. This species bears a wide range in the Indo-West Pacific waters, though some intervening localities are unknown to date. In the Japanese waters it is known from the south of Shiriya-zaki, Aomori Prefecture, southwards to the west of Kyushu and the East China Sea at the depths of 50 to $452 \mathrm{~m}$. The overseas localities are the Andaman Sea, 480-730 m deep, the Zanzibar Canal, $463 \mathrm{~m}$ deep and off the east coast of Africa, $638 \mathrm{~m}$ deep. This species usually inhabits more deeper water than the preceding species. 


\section{Family Thelxiopidae \\ Genus Latreillopsis Henderson, 1888 \\ Latreillopsis bispinosa Henderson, 1888}

Latreillopsis bispinosa Henderson, 1888, p. 22, pl. 2, fig. 3-Off Zebu, Philippines, 170 $\mathrm{m}$ deep.

Latreillopsis bispinosa, Alcock, 1899, p. 118-Andaman Sea, $95 \mathrm{~m}$ deep.

Latreillopsis bispinosa, Alcock, 1899a, p. 166-No new locality.

Latreillopsis bispinosa, Doflein, 1902, p. 650, pl. 4, figs. 3, 4-Sagami Bay.

Latreillopsis bispinosa, Ihle, 1913, p. 77-Kei Is., $90 \mathrm{~m}$ deep.

Latreillopsis bispinosa, Balss, 1922, p. 115-Sagami Bay, $80 \mathrm{~m}$ deep.

Latreillopsis bispinosa, Yokoya, 1933, p. 103-Bungo Str. and off Miyazaki Pref., 106-210 $\mathrm{m}$ deep.

Latreillopsis bispinosa, Sakai, 1934, p. 282-Nagasaki.

Latreillopsis bispinosa, Sakai, 1936, p. 36, pl. 3, fig. 3-Japan.

Latreillopsis bispinosa, Sakai, 1936 a, p. 53, pl. 2, fig. 2-Sagami Bay, Kii and Tosa Bay.

Latreillopsis bispinosa, Barnard, 1950, p. 343, fig. 65, g-Natal and off Cape Morgan, S. Afr., 135-155 $\mathrm{m}$ deep.

Latreillopsis bispinosa, Gordon, 1950, p. 244, fig. 22, a-Cape Natal.

Latreillopsis bispinosa, Miyake, 1961, p. 13-No new locality.

Latreillopsis bispinosa, Sakai, 1965, p. 16, pl. 7, fig. 1-Sagami Bay, 50-120 m deep.

Material examined.

$27^{\circ} 55^{\prime} \mathrm{N}, 123^{\circ} 35^{\prime} \mathrm{E} ; 1 \sigma^{\prime}$, ZLKU No. $13450 ;$ April 9, $1962 ; \mathrm{H}$. Yamashita leg.

Measurements.

$\sigma$ (No. 13450): Length of carapace in median line excluding rostral spine, $11.0 \mathrm{~mm}$; length of rostral spine, $2.2 \mathrm{~mm}$; length of pseudo. rostral spine along inner border, $4.5 \mathrm{~mm}$; breadth of carapace including branchial teeth, $9.8 \mathrm{~mm}$; the same excluding branchial teeth, $8.8 \mathrm{~mm}$.

Distribution. This species is widely distributed in the Indo-West Pacific waters from Japan through the Kei Islands and the Andaman Sea as far as South Africa. In Japan it has previously been known from Sagami Bay to the east coast of Kyushu. Its bathymetric range is from 50 to $210 \mathrm{~m}$.

\section{Family Dorippidae}

Genus Paradorippe Serène et Romimohtarto, 1969

Paradorippe granulata (de Haan, 1841)

Dorippe sima, de Haan, 1839, pl. 31, fig. 2. 
Dorippe granulata de Haan, 1841, p. 122-Japan.

Dorippe granulata, Ortmann, 1892, p. 31-Kadsiyama (=Katsuyama), Tanagava (?) and Kagoshima; Hongkong.

Dorippe granulata, Rathbun, 1902, p. 31-Miyako, Kii and Nagasaki.

Dorippe granulata, Stimpson, 1907, p. 167-Hakodate Bay and north-east of Japan, 10-55 $\mathrm{m}$ deep ; Hongkong, $20 \mathrm{~m}$ deep.

Dorippe granulata, Parisi, 1914, p. 301-Hakodate Bay, Tokyo Bay and Suruga Bay.

Dorippe granulata, Balss, 1922, p. 119-Vladivostok; Aomori, Onagawa, Tateyama, Kominato, Tokyo Bay, Sagami Bay, Kii and Nagasaki, 8-45 m deep.

Dorippe granulata, Shen, 1932, p. 15, figs. 8, 9, pl. 1, fig. 12-Shantung Penin., North China.

Dorippe granulata, Yokoya, 1933, p. 107-Near Todo-zaki, Kinkazan, Inubo-zaki, Suruga Bay, Kii, Goto Is., Tsu-shima Str., north of Oga and west of Lake Jusangata, 18-154 $\mathrm{m}$ deep.

Dorippe granulata, Sakai, 1934, p. 283-Nagasaki.

Dorippe granulata, Sakai, 1936, p. 41, pl. 6, fig. 4-Japan.

Dorippe granulata, Sakai, 1937, p. 74, pl. 10, fig. 5-Tokyo Bay, Sagami Bay, Shimoda, Ise Bay and Kii; Inchon, Korea.

Dorippe granulata, Miyake, 1961, p. 13-No new locality.

Dorippe granulata, Miyake, 1961a, p. 170-Sea of Ariaké.

Dorippe granulata, Sakai, 1965, p. 22, pl. 11, fig. 1-Sagami Bay, 35-80 m deep.

Paradorippe granulata, Serène and Romimohtarto, 1969, p. 15, figs. 23-25, 29, pl. 2, fig. C, pl. 6, fig. C-Mikawa Bay.

Material examined.

East China Sea without definite locality; $2 \delta^{\lambda} \sigma^{\top}$, ZLKU No. 290 ; August 1953; H. Maéda leg.

Off Chilung, Taiwan; 1 ovig. + , ZLKU No. 13357; November 1966; Taiwan Mar. Res. Inst. leg., received through Mr. H. P. Yu.

\section{Measurements.}

$\sigma^{7} \sigma^{x}$ (No. 290): Length of carapace in median line, 24.0 and $21.3 \mathrm{~mm}$; breadth of carapace, 26.7 and $23.8 \mathrm{~mm}$.

Ovig. 우 (No. 13357) : Length of carapace in median line, $19.4 \mathrm{~mm}$; breadth of carapace, $21.3 \mathrm{~mm}$.

Distribution. This species is restricted to the West Pacific, ranging from Vladivostok southwards to Hongkong. In Japan it is known from Hakodate Bay southwards to the west of Kyushu along both coasts at the depths of 8 to $154 \mathrm{~m}$.

\section{Genus Ethusa Roux, 1830}

\section{Ethusa quadrata Sakai, 1937}

Ethusa quadrata Sakai, 1937, p. 78, fige. 1, c, 3-Sagami Bay, 50-100 m deep.

Ethusa quadrata, Sakai, 1965, p. 24, pl. 12, fig. 3-Sagami Bay, 35-120 m deep. 


\section{Material examined.}

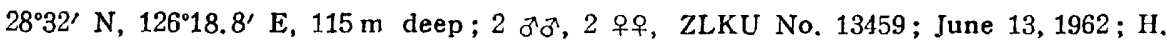
Yamashita leg.

$29^{\circ} 55.5^{\prime} \mathrm{N}, 127^{\circ} 22.9^{\prime} \mathrm{E}, 126 \mathrm{~m}$ deep; $13^{7}$, ZLKU No. 13463; December 5, 1967; H. Yamashita leg.

$31^{\circ} 29.2^{\prime} \mathrm{N}, 130^{\circ} 1.5^{\prime}$ E, $196 \mathrm{~m}$ deep ; $1 \delta^{\prime}$, ZLKU No. 13464 ; June 13, 1964 ; H. Yamashita leg.

$31^{\circ} 31.7^{\prime} \mathrm{N}, 127^{\circ} 27.4^{\prime} \mathrm{E}, 128 \mathrm{~m}$ deep; 1 ovig. 우, ZLKU No, 13465 ; July 9, 1962 ; II. Yamashita leg.

$33^{\circ} 9.2^{\prime} \mathrm{N}, 128^{\circ} 1.4^{\prime} \mathrm{E}, 158 \mathrm{~m}$ deep ; 1 우, ZLKU No. 13466 ; June 18, 1964 ; H. Yamashita leg.

\section{Measurements,}

$\delta శ$ (No. 13459-1 and 13464): Length of carapace in median line, 6.0 and $5.5 \mathrm{~mm}$; the same including frontal teeth, 6.5 and $6.0 \mathrm{~mm}$; breadth of carapace, 5.0 and $4.4 \mathrm{~mm}$.

Ovig. 우 (No. 13465) : Length of carapace in median line, $7.9 \mathrm{~mm}$; the same including frontal teeth, $8.9 \mathrm{~mm}$; breadth of carapace, $7.3 \mathrm{~mm}$.

우우(No. 13459-3 and 13466): Length of carapace in median line, 8.0 and $6.9 \mathrm{~mm}$; the same including frontal teeth, 8.9 and $7.5 \mathrm{~mm}$; breadth of carapace, 7.3 and $5.8 \mathrm{~mm}$.

Distribution. This species has previously recorded from scveral stations in Sagami Bay at the depths of 35 to $120 \mathrm{~m}$. The geographical and bathymetric ranges are therefore further extended southwards to the East China Sea and down to $196 \mathrm{~m}$, respectively.

\section{Ethusa minuta Sakai, 1937}

Ethusa minuta Sakai, 1937, p. 81, figs. 1, e, 5, pl. 11, fig. 2-Sagami Bay and Shimo$\mathrm{da}, 50-80 \mathrm{~m}$ deep.

Ethusa minuta, Sakai, 1965, p. 23, pl. 11, fig. 4-Sagami Bay, $85 \mathrm{~m}$ deep.

\section{Material examined.}

$28^{\circ} 32^{\prime} \mathrm{N}, 126^{\circ} 188^{\prime} \mathrm{E}, 115 \mathrm{~m}$ deep; $10^{\wedge}, 1$ ovig. 우, 1 ㅇ, 1 juv., ZLKU No. 13451 ; June 13,$1962 ;$ H. Yamashita leg.

$31^{\circ} 19.5^{\prime} \mathrm{N}, 127^{\circ} 32^{\prime} \mathrm{E}, 126 \mathrm{~m}$ deep ; $13^{\wedge}, 299$. ZLKU No. 13455; June 17, 1964 ; H. Yamashita leg.

$31^{\circ} 29.7^{\prime} \mathrm{N}, 120^{\circ} 1.3^{\prime}$ E, $146 \mathrm{~m}$ deep; 1 ovig. ㅇ. ZLKU No. 13458; June 14, $1964 ; \mathrm{H}$. Yamashita leg.

\section{Measurements.}

$\sigma$ (No. 13451-1): Length of carapace in median line, $5.5 \mathrm{~mm}$; the same including frontal teeth, $6.0 \mathrm{~mm}$; breadth of carapace, $4.9 \mathrm{~mm}$.

Ovig. 우우 (No. 13451-2 and 13458): Length of carapace in median line, 5.9 and $5.0 \mathrm{~mm}$; the same including frontal teeth, 6.4 and $5.3 \mathrm{~mm}$; breadth of carapace, 5.5 and $4.9 \mathrm{~mm}$. 
우우 (No. 13455): Length of carapace in median line, 9.0 and $9.8 \mathrm{~mm}$; the same including frontal teeth, 10.0 and $9.8 \mathrm{~mm}$; breadth of carapace, 9.0 and $8.8 \mathrm{~mm}$.

Remarks. The hairiness and granulation of the dorsal surface of the carapace, and the formation of the frontal and external orbital teeth are very variable. Those features as well as the frontal and external orbital teeth are close to those of E. izuensis Sakai. In the present species, however, the anterior extremity of the spout extends far beyond the level of the antennular basal segment and touches the ventral surface of the front, so that the epistome is not defined at all. This feature is very important for the discrimination of the present species from $E$. izuensis in which the anterior extremity of the spout also extends far beyond the level of the antennular basal segment, but does not touch the front.

Distribution. This species has previously been recorded from Sagami Bay and Shimoda at the depths of 50 to $85 \mathrm{~m}$. It extends the geographical range southwards to the East China Sea and the bathymetric range down to $146 \mathrm{~m}$.

\section{Family Leucosiidae \\ Genus Ebalia Leach, 1817}

\section{Ebalia tuberculosa (A. Milne Edwards, 1873)}

Persephona tuberculosa A. Milne Edwards, 1873, p. 262-Bass Strait.

Phlyxia granulosa Haswell, 1879, p. 54, pl. 6, fig. 3-Off Sydney.

Ebalia tuberculosa, Miers, 1886, p. 306, pl. 25, fig. 1-Port Jackson, off Twofold Bay and Bass Str., 55-270 $\mathrm{m}$ deep ; New Zealand, $270 \mathrm{~m}$ deep.

Ebalia tuberculosa, Whitelegge, 1900, p. 161-Off Cape Three Points, Port Hacking, Botany Bay, Port Kembla and Wata Mooli, N. S. W., 40-135 m deep.

Ebalia salamensis Doflein, 1904, p. 47, pl. 16, figs. 1-3-Off Dar es Salaam, $400 \mathrm{~m}$ deep. Ebalia tuberculosa, Grant, 1905, p. 315-Off Port Jackson, $550 \mathrm{~m}$ deep.

Ebalia tuberculosa, Rathbun, 1906, p. 889-Oahu I., Molokai I., Pailolo Channel and Hawaii I., Hawaiian Is., 55-380 $\mathrm{m}$ deep.

Nursia scandens Stebbing, 1920, p. 247, pl. 26, fig. A-Off Cove Rock, S. Afr., 145-250 m deep.

Nursia postulans Stebbing, 1921, p. 461, pl. 18, fig. A-Off Cape Natal, $330 \mathrm{~m}$ deep.

Nursia scandens, Stebbing, 1921, pl. 18, fig. B.

Ebalia tuberculosa, Rathbun, 1923, p. 134, pl. 35, figs. 1,2-Bass Str. and Great Australian Bight, $120-360 \mathrm{~m}$ deep.

Ebalia tubesculosa, Hale, 1927, p. 197, fig. 198-S. Aust.

Ebalia japonica Rathbun, 1932, p. 37-Off Niigata, $125 \mathrm{~m}$ deep.

Ebalia japonica, Yokoya, 1933, p. 119-Numerous localities around Japan but Hokkaido, 73-402 m deep. 
Ebalia japonica, Sakai, 1936, p. 53, fig. 14-Japan.

Ebalia tuberculosa, Sakai, 1937, p. 111, fig. 11-Sagami Bay and Izu; Twofold Bay, Aust.

Ebalia tuberculosa, Barnard, 1946, p. 373-No locality.

Ebalia tuberculosa, Barnard, 1950, p. 368, fig. 70, h-k-Off Gt. Fish Point, S. Afr,, $180 \mathrm{~m}$ deep.

Ebalia tuberculosa, Bennett, 1964, p. 22-No new locality.

Ebalia tuberculosa, Sakai, 1965, p. 28, pl. 13, fig. 2-Sagami Bay, 85-120 m deep.

Material examined.

$31^{\circ} 29.2^{\prime} \mathrm{N}, 130^{\circ} 1.5^{\prime} \mathrm{E}, 196 \mathrm{~m}$ deep ; $10^{\prime}$, ZLKU No. 13467 ; June 13, 1964 ; II. Yamashita leg.

$31^{\circ} 29.8^{\prime} \mathrm{N}, 128^{\circ} 1.5^{\prime} \mathrm{E}, 145 \mathrm{~m}$ deep ; 1 우, ZLKU No. 13468 ; June 23,$1963 ;$ H. Yamashita leg.

$33^{\circ} 9.2^{\prime} \mathrm{N}, 128^{\circ} 1.4^{\prime} \mathrm{E}, 158 \mathrm{~m}$ deep; $13^{`}, 2$ juv., ZLKU No. 13469 ; June 18, 1964 ; II. Yamashita leg.

33'23.4' N, $129^{\circ} 3.9^{\prime}$ E, $100 \mathrm{~m}$ deep; 2 우우, ZLKU No. 13472 ; June 18, 1964 ; H. Yamashita leg.

$33^{\circ} 34.9^{\prime} \mathrm{N}, 128^{\circ} 25.2^{\prime} \mathrm{E}, 120 \mathrm{~m}$ deep; 1 우, ZLKU No. 13474 ; June 18,$1964 ;$ H. Yamashita leg.

Measurements.

$\delta^{7} \sigma^{7}$ (No. 13467 and 13469-1): Length of carapace, 5.5 and $4.2 \mathrm{~mm}$; breadth of carapace, 5.3 and $3.9 \mathrm{~mm}$.

우 (No. 13472-1 and 13474): Length of carapace, 6.1 and $5.9 \mathrm{~mm}$; breadth of carapace, 6.0 and $5.9 \mathrm{~mm}$.

Distribution. This polymorphic species is very widely distributed in the whole Indo-West Pacific waters from Japan and the Hawaiian Islands to Australia and also to South Africa. The occurrence in New Zealand recorded by Miers (1886) is, however, somewhat doubtful. In Japan it is recorded from numerous localities around Honshu, Shikoku and Kyushu. It is known from rather shallow water, about $40 \mathrm{~m}$, to deep water down to $550 \mathrm{~m}$.

\section{Ebalia longimana Ortmann, 1892}

Arcania orientalis Miers, 1879, p. 44 (non Ebalia orientalis Kossmann, 1877)-Kii and Goto Is., 55-65 m deep.

Ebalia longimana Ortmann, 1892, p. 578, pl. 26, fig. 13-Sagami Bay, Kadsiyama (=Katsuyama) and Wakasa Bay, 50-180 m deep.

Ebalia gotoensis Rathbun, 1932, p. 36-Goto Is., 110-120 m deep.

Ebalia longimana, Yokoya, 1933, p. 118-Sagami Bay, Suruga Bay, south of Omaézaki, Tosa Bay, Bungo Str., Goto Is., north of Kyushu, off Yamaguchi Pref. and Wakasa Bay, 51-307 $\mathrm{m}$ deep.

Ebalia longimana, Sakai, 1936, p. 51, fig. 12, pl. 9, fig. 5-Japan. 
Ebalia longimana, Sakai, 1937, p. 109, fig. 10, pl. 13, fig. 10, 6-Sagami Bay and Shimoda. Arcania orientalis, Sakai, 1937, p. 128-No new locality.

Ebalia longimana, Sakai, 1965, p. 29, pl. 13, figs. 5, 6-Sagami Bay, 30-85 m deep.

\section{Material examined.}

$27^{\circ} 14.5^{\prime} \mathrm{N}, 124^{\circ} 45^{\prime} \mathrm{E}, 98 \mathrm{~m}$ deep; 1 iq infested by Sacculina, ZLKU No. 13476 ; June 12,$1962 ;$ H. Yamashita leg.

$31^{\circ} 9.5^{\prime} \mathrm{N}, 127^{\circ} 16^{\prime} \mathrm{E}, 111 \mathrm{~m}$ deep; $1{ }^{\circ}, \mathrm{ZLKU}$ No. 13477 ; March 26,1964 ; H. Yamashita leg.

$31^{\circ} 19.5^{\prime} \mathrm{N}, 127^{\circ} 32^{\prime} \mathrm{E}, 126 \mathrm{~m}$ deep ; $1 \sigma^{\star}, \mathrm{ZLKU}$ No. 13478 ; June 17,1964 ; H. Yamashita leg.

$31^{\circ} 29.2^{\prime} \mathrm{N}, 130^{\circ} 1.5^{\prime} \mathrm{E}, 196 \mathrm{~m}$ deep ; $1 \sigma^{\star}$ infested by bopyrid, ZLKU No. 13479 ; June 13,$1964 ;$ H. Yamashita leg.

$31^{\circ} 30^{\prime} \mathrm{N}, 127^{\circ} 13.8^{\prime} \mathrm{E}, 107 \mathrm{~m}$ deep ; $1 \sigma^{\prime}$, ZLKU No. 13480 ; July 8, 1962; H. Yamashita leg.

$33^{\circ} 9.2^{\prime} \mathrm{N}, 128^{\circ} 1.4^{\prime} \mathrm{E}, 158 \mathrm{~m}$ deep; 1 오, ZLKU No. 13481 ; June 18,$1964 ; \mathrm{H}$. Yamashita leg.

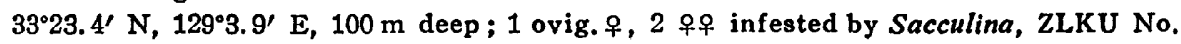
13484 ; June 18,1964 ; H. Yamashita leg.

\section{Measurements.}

$\delta^{\top} \delta^{\prime}$ (No. 13480 and 13478$)$ : Length of carapace, 4.8 and $3.8 \mathrm{~mm}$; breadth of carapace, 4.7 and $4.0 \mathrm{~mm}$.

Ovig. ㅇ (No. 13484-1): Length of carapace, $4.9 \mathrm{~mm}$; breadth of carapace, $5.2 \mathrm{~mm}$.

우우(No. 13481 and 13484-2): Length of carapace, 6.0 and $5.2 \mathrm{~mm}$; breadth of carapace, 6.5 and $5.4 \mathrm{~mm}$.

Remarks. The male abdomen consists of four pieces, the formula being $1+2+R+T$. Near the distal end of the fused segment is a median large tubercle that is rather deeply excavated at its proximal part. The terminal segment is elongate, being about half the length of the fused segment. The first and second male pleopods are slender, the second being the longer. The abdominal formula of the female is $1+2+R+T$.

Distribution. This species is known from Sagami Bay southwards to the west of Kyushu along the Pacific coast and from the Goto Islands northwards to Wakasa Bay. Its bathymetric range is from 30 to $307 \mathrm{~m}$.

\section{Ebalia scabriuscula Ortmann, 1892}

Ebalia scabriuscula Ortmann, 1892 , p. 580 , pl. 26, fig. 14-Sagami Bay, $180 \mathrm{~m}$ deep. Ebalia scabriuscula, Balss, 1922, p. 127-Sagami Bay, $250 \mathrm{~m}$ deep. 
Ebalia scabriscula, Yokoya, 1933, p. 117-Sagami Bay, Suruga Bay, Tosa Bay, Bungo Str., east of Kagoshima Pref. and Goto Is., 106-658 m deep.

Ebalia scabriuscula, Sakai, 1936, p. 52, fig. 13, pl. 9, fig. 2-Japan.

Ebalia scabriuscula, Sakai, 1937, p. 107, fig. 9-Sagami Bay and Kii.

Ebalia scabriuscula, Sakai, 1965, p. 28, pl. 13, fig. 3-Sagami Bay, 65-85 m deep.

Material examined.

$31^{\circ} 19.5^{\prime} \mathrm{N}, 127^{\circ} 32^{\prime} \mathrm{E}, 126 \mathrm{~m}$ deep; $1 \mathrm{o}^{\prime}$, ZLKU No. 13475 ; June 18, $1964 ; \mathrm{H}$. Yamashita leg.

\section{Measurements.}

o (No 13475): Length of carapace, $6.4 \mathrm{~mm}$; breadth of carapace, $7.8 \mathrm{~mm}$.

Remarks. The male abdomen is composed of five segments (formula $1+2+R+6+T)$, though the second segment is very short. The first male pleopod is very short. According to Sakai (1937), the female abdomen also consists of five pieces, the fourth to sixth segments being fused. The abdominal formula of the female is therefore $1+2+3+R+T$.

Distribution. This species is restricted to the Japanese waters from Sagami Bay southwards to the Goto Islands, the west of Kyushu along the Pacific coast, and also to the East China Sea as recorded at present. Its bathymetric range is from 65 to $658 \mathrm{~m}$.

Genus Merocryptus A. Milne Edwards, 1873

Merocryptus lambriformis A. Milne Edwards, 1873

Merocryptus lambriformis A. Milne Edwards, 1873, p. 85, pl. 13, fig. 1-Upolu, Samoa Is.

Merocryptus lambriformis, Miers, 1886, p. 320-Twofold Bay and Bass Str., 70-270 m deep.

Merocryptus lambriformis, Whitelegge, 1900, p. 162-Off Narrabine and Port Hacking, N.S.W., 35-150 $\mathrm{m}$ deep.

Merocryptus lambriformis, Balss, 1922, p. 126-Sagami Bay.

Merocryptus lambriformis, Rathbun, 1923, p. 133, pl, 32, figs. 2, 3-Bass Str. and Great Australian Bight, $115-215 \mathrm{~m}$ deep.

Merocryptus lambriformis, Hale, 1927, p. 201, fig. 202-S. Aust.

Ebalia rugosa Yokoya, 1933, p. 124, fig. 43-Suruga Bay, Kii and Goto Is., 128-190 m deep.

Merocryptus lámbriformis, Sakai, 1937, p. 113, pl.13, fig. 7-Sagami Bay and N.S.W., Aust.

Merocryptus lambriformis, Bennett, 1964, p. 22, fig.108-Off Little Barrier, N.Z., $65 \mathrm{~m}$ deep.

Merocryptus lambriformis, Sakai, 1965, p. 30, fig. 3, c, pl. 14, figs. 1, 2-Sagami Bay, 85-95 $\mathrm{m}$ deep. 
Merocryptus lambriformis, Kim, 1966, p. 401, fig. 3, pl. 1, fig. 2-Cheju Do I., $60 \mathrm{~m}$ deep.

Merocryptus lambriformis, Dell, 1968, p. 13, pl. 1-Off Patea, N.Z., $70 \mathrm{~m}$ deep.

Material examined.

$28^{\circ} 32^{\prime} \mathrm{N}, 126^{\circ} 18.8^{\prime} \mathrm{E}, 115 \mathrm{~m}$ deep ; $1 \delta^{\wedge}$, ZLKU No. 13485 ; June 13,1962 ; II. Yamashita leg.

Measurements,

$\partial$ (No. 13485): Length of carapace including frontal lateral teeth and posterolateral projections, $9.5 \mathrm{~mm}$; breadth of carapace including branchial outgrowths, $11.4 \mathrm{~mm}$; the same excluding branchial outgrowths, $9.0 \mathrm{~mm}$.

Remarks. This distinctive species is well known by its characteristic carina on each branchial region, that is prolonged obliquely backwards to form a wing-like projection.

At present in the Zoological Laboratory, Kyushu University are eleven specimens collected by S. S. Soyo-Maru and reported by Yokoya (1933) as Ebalia rugosa. Most of the specimens are dry, and the ambulatory legs are detached. Of those the four specimens from the station 325 were probably not reported by Yokoya.

St. 211, near Tanabe, Wakayama-ken, $190 \mathrm{~m}$ deep. July 14, 1927. 3 우우.

St. 266, Suruga Bay, $128 \mathrm{~m}$ deep. November 18, 1927. 1 우.

St. 316, Bungo Strait, $190 \mathrm{~m}$ deep. July 16, 1928. 1 우.

St. 325, Bungo Strait, $210 \mathrm{~m}$ deep. July 21, 1928. 1 đ 3 우우.

St. 431, south-west of Goto Is., $152 \mathrm{~m}$ deep. July 16, 1929. 1 우.

St. 440, south-west of Goto Is., $152 \mathrm{~m}$ deep. July 19, 1929. 1 Ђ゙.

Distribution. This species is known from Japan, the Samoa Islands, Australia and New Zealand. In Australia it ranges from off the coast of New South Wales through the Bass Strait to the Great Australian Bight. In Japan it is known from Sagami Bay southwards to the west of Kyushu and to the East China Sea at present reported. The bathymetric range is from 35 to $270 \mathrm{~m}$.

Genus Praebebalia Rathbun, 1911

Praebebalia longidactyla Yokoya, 1933 (Fig. 4)

Praebebalia longidactyla Yokoya, 1933, p. 125, fig. 44-Suruga Bay. Kii, Bungo Str. and Goto Is., 123-190 $\mathrm{m}$ deep.

Praebebalia longidactyla, Sakai, 1937, p. 113-No new locality. 
Description. The carapace is globular and as long as wide. The dorsal surface is ill-defined only with low prominences at the hepatic and intestinal regions, being thickly and uniformly covered with micro. scopical granules. The frontal region is raised and separated into two lobes by a median dorsal, deep sulcus. The anterior border of each lobe is nearly truncated, or only weakly concave in the middle. In the dorsal view, each of the lateral part of the median V-shaped sinus is weakly produced, and the supraorbital angle is sharply an. gulated.

The chelipeds are exceedingly long in both sexes. The merus, carpus and palm are subcylindrical and thickly covered with microscopical granules like the carapace. The fingers are slender, and distinctly exceed half the length of the palm, but not reach the length of the palm. The cutting edges are irregularly and minutely toothed along the whole length, and several teeth of each cutting edge are more or less prominent. The tips of both fingers are strongly crossed, being curved upwards and downwards, respectively. The ambulatory legs are slender, and those of the male are slightly stouter than those of the female. In all the legs the dactyli are distinctly longer than the propodi. In the male ambulatory legs each of the propodus of the first two pairs bears a low lamellar prominence near the distal end of its lower border. That of the second pair is, however, very obscure. The last two pairs of the male ambulatory legs are alike the female ones.

The male abdomen is markedly wide and composed of four pieces, the third to sixth segments being fused. The abdominal formula of the male is therefore $1+2+R+T$. The female abdomen is composed of three pieces, the formula being probably $2+R+T$. The second male pleopod is subfiliform, twisted and longer than the first one. In one male (No. 13491) it is straightened, but each of the other specimens is recurved towards the proximal part in the natural position.

\section{Material examined.}

$31^{\circ} 29.7^{\prime} \mathrm{N}, 128^{\circ} 1.3^{\prime} \mathrm{E}, 146 \mathrm{~m}$ deep ; $1 \delta^{\prime}, 2$ ovig. 우우, ZLKU No. 13486; June 14, 1964;

II. Yamashita leg.

$31^{\circ} 29.8^{\prime} \mathrm{N}, 128^{\circ} 1.5^{\prime} \mathrm{E}, 145 \mathrm{~m}$ deep; $1 \delta^{7}, 1$ ovig. 우, ZLKU No. 13489; June 13, 1963;

H. Yamashita leg.

$33^{\circ} 9.2^{\prime} \mathrm{N}, 128^{\circ} 1.4^{\prime}$ E, $158 \mathrm{~m}$ deep; $10^{\prime \prime}$, ZLKU No. 13490 ; June 18, 1964 ; H. Yamashita leg.

$34^{\circ} 25.3^{\prime} \mathrm{N}, 129^{\circ} 5.3^{\prime} \mathrm{E}, 150 \mathrm{~m}$ deep ; $1 \delta^{\dagger}$. ZLKU No. 13491 ; June 19, 1964 ; II. Yamashita leg.

Measurements.

$ð$ (No. 13486-1): Length of carapace, $5.2 \mathrm{~mm}$; breadth of carapace, 5.0 
mm. $\sigma^{-1}$ (No. 13489-1): Length of carapace, $5.4 \mathrm{~mm}$; breadth of carapace, $5.2 \mathrm{~mm}$. $\sigma$ (No. 13490): Length of carapace, $4.5 \mathrm{~mm}$; breadth of carapace, $4.3 \mathrm{~mm}$. $\sigma^{\top}$ (No. 13491): Length and breadth of carapace, $5.8 \mathrm{~mm}$.

Ovig. 우우(No. 13486-2,3): Length of carapace, 5.4 and $5.1 \mathrm{~mm}$; breadth of carapace, 5.3 and $5.1 \mathrm{~mm}$. Ovig. + (No. 13489-2): Length of carapace, $5.2 \mathrm{~mm}$; breadth of carapace, $5.3 \mathrm{~mm}$.

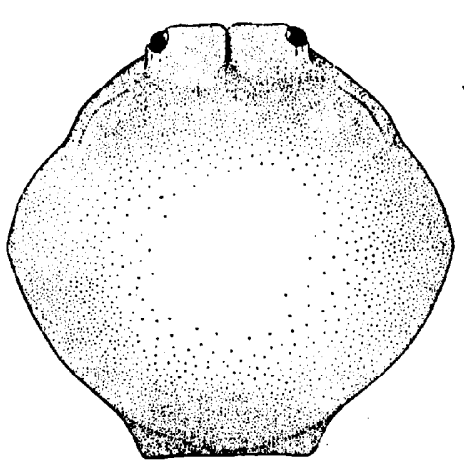

A
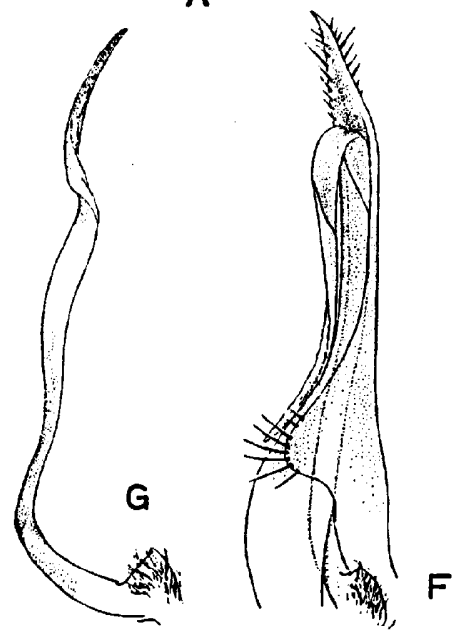
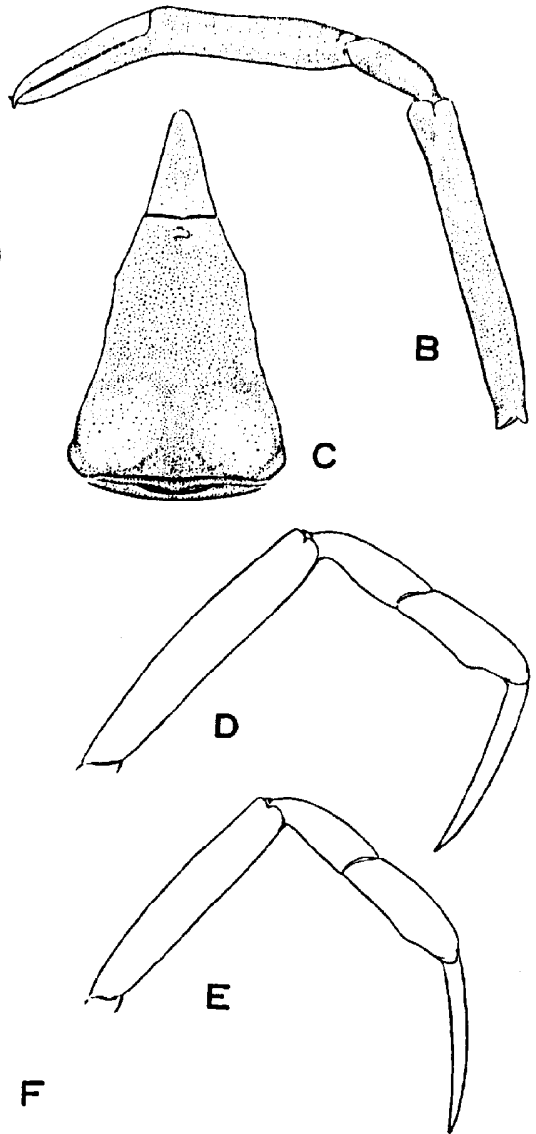

Fig. 4. Praebebalia longidactyla Yokoya. A, carapace of syntype, $\sigma^{7}(5.5 \times 5.5 \mathrm{~mm}) ; B$, right cheliped of $\sigma^{3}(5.2 \times 5.0 \mathrm{~mm}), \times 5$; $C$, abdomen of the same $\pi, \times 10 ; D, E$, first and second ambulatory legs of the same $\sigma, \times 10 ; F$, left first and second male pleopods of the same $\sigma$ in situ in abdominal view, $\times 25 ; \mathrm{G}$, left second pleopod of $\pi(5.8 \times 5.8 \mathrm{~mm})$ in abdominal view, $\times 20$. 
Remarks. The present specimens examined were compared with the syntypes of the present species. Altogether four specimens listed below are now preserved in the Zoological Laboratory, Kyushu University. They are in spirit but in a bad state of preservation, and all the chelipeds and ambulatory legs are missing.

St. 316, Bungo Strait, $190 \mathrm{~m}$ deep. July 16, 1928. 1 శ 1 ? .

St. 451, west of Goto Is., $187 \mathrm{~m}$ deep. July 22, 1929, 1 ठ 1 우.

The formation of the carapace is nearly identical with that of $P$. pisiformis Ihle, and in reality the distinction appears to be almost im. possible. According to the original description, the fingers are slightly longer than the palm, being one and one-fourth as long as the palm. In both sexes of the present specimens the fingers are shorter than the palm, but distinctly exceed half the length of the palm. In $P$. pisiformis, however, the fingers are rather short, being about half the length of the palm. In addition, the dactyli of the ambulatory legs of the present species are possibly longer than those of $P$. pisiformis. Unfortunately, as $\boldsymbol{P}$. pisiformis is known to date by only a female from the Samau Strait, $390 \mathrm{~m}$ deep, the male abdomen and pleopods are not available for comparison.

Distribution. This species was originally recorded from Suruga Bay, the Kii province, the Bungo Strait and the west of the Goto Islands at the depths of 123 to $190 \mathrm{~m}$.

Genus Actaeomorpha Miers, 1878

Actaeomorpha morum Alcock, 1896

Actaeomorpha morum Alcock, 1896, p. 172, pl. 8, fig. 3-Off Ganjam coast, India, 50$55 \mathrm{~m}$ deep.

Actaeomorpha morum, Illust. Zool. Invest., Crust., 1896, pl. 28, fig. 4.

Oreophorus rugosus, Yokoya, 1933, p. 116-East of Kagoshima Pref., $115 \mathrm{~m}$ deep.

Actaeomorpha morum, Chopra, 1934, p. 480-Off River Hooghly, Bay of Bengal, $35 \mathrm{~m}$ deep.

Actaeomorpha morum, Edmondson, 1935, p. 20 (in key).

Actaeomorpha morum, Sakai, 1937, p. 116, fig. 13-Sagami Bay.

Actaeomorpha morum, Serène, 1954, p. 458, figs. 1, 2, pl. 7-Viet Nam.

Actaeomorpha morum, Sakai, 1965, p. 35, pl. 15, fig. 3-Sagami Bay, 55-65 m deep.

Material examined.

$27^{\circ} 14.5^{\prime} \mathrm{N}, 124^{\circ} 45^{\prime} \mathrm{E} ; 1 \mathrm{o}^{\dagger}$, ZLKU No. 13192 ; June 12, 1962 ; H. Yamashita leg.

$29^{\circ} 59.5^{\prime} \mathrm{N}, 126^{\circ} 14.8^{\prime} \mathrm{E}, 85 \mathrm{~m}$ deep; 1 우, ZLKU No. 13493 ; June 28, 1963; H. Yamashita leg.

Measurements.

o (No. 13492): Length of carapace, $7.3 \mathrm{~mm}$; breadth of carapace, $8.7 \mathrm{~mm}$. 
. (No. 13493) : Length of carapace, $10.3 \mathrm{~mm}$; breadth of carapace, 12.5 $\mathrm{mm}$.

Remarks. The peculiar species is readily distinguished from the congeners due to the fine figures and descriptions given by the previous authors. A female reported by Yokoya (1933) as Oreophorus rugosus Stimpson is now preserved in the Zoological Laboratory, Kyushu University, and without doubt referable to the present species.

Distribution. This species ranges from Japan through the coast of Viet Nam to off the River Hooghly and off the Ganjam coast of India faced to the Bay of Bengal. Its bathymetric range is from 35 to $115 \mathrm{~m}$.

Genus Nursia Leach, 1817

Nursia rhomboidalis (Miers, 1879)

(Fig. 5, Pl. 1, Figs. C, D)

Ebalia rhomboidalis Miers, 1879 , p. 42-No definite locality.

Nursia rhomboidalis, Sakai, 1965, p. 39, fig. 5, a, b-Kii and Inland Sea of Japan.

Material examined.

$31^{\circ} \mathrm{N}, 124^{\circ} 21.5^{\prime} \mathrm{E}, 45 \mathrm{~m}$ deep; 7 đo $ð^{7}, 1$ ovig. 우, 1 우, ZLKU No. 13495; July 3, 1962;

II. Yamashita leg.

Measurements.

$\sigma^{\curvearrowright}($ No. 13495-1, 2): Length of carapace including posterior lobe, 14.0 and $13.8 \mathrm{~mm}$; breadth of carapace, 18.8 and $18.3 \mathrm{~mm}$.

Ovig. + (No. 13495-8) : Length of carapace including posterior lobe, $11.0 \mathrm{~mm}$; breadth of carapace, $13.4 \mathrm{~mm}$.

Remarks. The present specimens are safely referable to the present species which was recently transferred to the genus Nursia after the examination of the type-specimen by Sakai (1965). The following short notes on the variation and also on some features may supply the original brief description.

The contour of the carapace is somewhat different in both sexes, and the formation of the anterolateral and posterolateral borders of the carapace is variable. In the adult male the carapace is proportionally wider than in the female carapace, but in the smaller male the proportion of the carapace is similar to that of the female. In the male two lobular outgrowths directed posteriorly and weakly downwards from the posterior border of the carapace are distinctly separated from each other by a wide $V$-shaped incision, while in the female they are indistinctly separated by a shallow depression. In both sexes 
each of the anterolateral borders of the carapace is usually nearly straight or slightly convex posteriorly with two or three very indistinct interruptions, but in some males a lobe is produced at the posterior end of the anterolateral border, being separated from the epibranchial angle by a deep notch. In the female and smaller male the posterior end of the anterolateral border and the epibranchial angle is united to form a straight border. The epibranchial angle is strongly produced and acute at the summit in the large male. The posterolateral border behind the epibranchial angle is also strongly concave in the large male and rather shallowly in the smaller male and the female.

The formation of the chelipeds and ambulatory legs is similar in both sexes, though the male chelipeds are enormously developed. The upper surface of the merus is entirely flattened, and its anterior and posterior borders are crested. The outer border of the carpus and

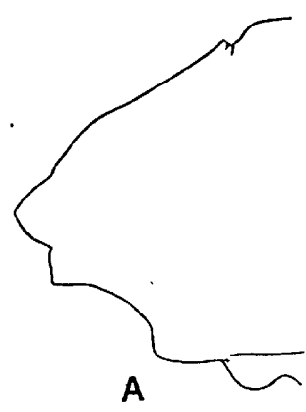

A

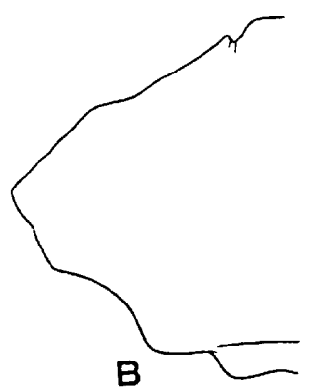

B
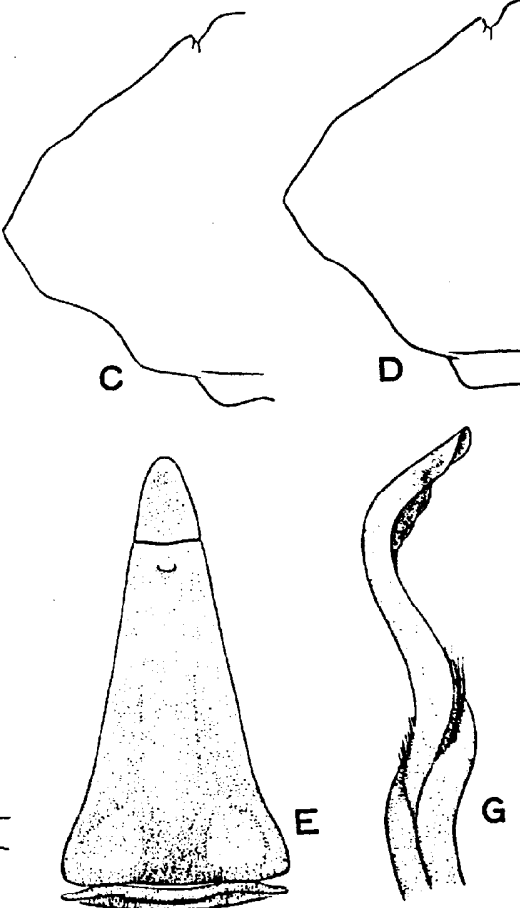

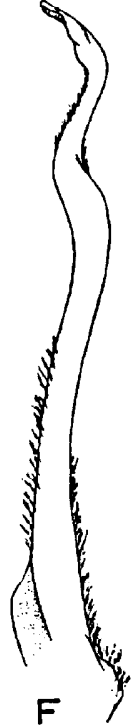

Fig. 5. Nursia rhomboidalis (Miers). $\Lambda$, left half of carapacial contour of $\delta^{-1}(14.0 \times 18.8 \mathrm{~mm}) ; B$, the same of $\sigma^{-7}(12.5 \times 16.8$ $\mathrm{mm}) ; \mathrm{C}$, the same of $3^{7}(11.4 \times 14.2 \mathrm{~mm}) ; \mathrm{D}$, the same of ovig. o $(11.0 \times 13.4 \mathrm{~mm})$; E, abdomen of $z^{7}(14.0 \times 18.8 \mathrm{~mm})$, $\times 5 ; F$, left first pleopod of the same $\sigma$ in abdominal view, $\times 10 ; G$, distal part of the same in sternal view, $\times 17.5$. 
both borders of the palm are also thin. Both cutting edges of the fingers are thin, finely toothed and well interlocked throughout the lengths. In the ambulatory legs both borders of the merus and propodus, and the upper border of the carpus are sharply crested. In addition, at the middle of the upper surface of the carpus is a longitudinal high crest that extends along the whole length of the segment. The dactylus is as long as the propodus and densely tomentose.

The male abdomen consists of four pieces, the formula being $1+2$ $+R+T$. The first two segments are linear, and the fused segment is very prominent. The fused segment is ornamented with a rounded prominence at each side of the proximal part, a longitudinal prominence at the middle and a small, median transverse tubercle near the distal end. The first male pleopod is curved outwards at the subterminal part and then distally inwards, the formation of the tip being complex. The abdominal formula of the female is $1+2+3+R+T$.

Distribution. This species has hitherto been recorded from the Kii province to the Inland Sea of Japan. The bathymetric range has not previously been recorded.

\section{Nursia japonica Sakai, 1935}

Nursia elegans japonica Sakai, 1935, p. 66, fig. 2-Sagami Bay, 80-100 m deep.

Nursia elegans japonica, Sakai, 1936, p. 53, fig. 15, pl. 9, fig. 4-Japan.

Nursia elegans japonica, Sakai, 1937, p. 121, pl. 14, fig. 3-Sagami Bay.

Nursia elegans japonica, Miyake, 1961a, p. 170-Sea of Ariaké.

Nursia elegans japonica, Sakai, 1965, p. 38, pl. 16, fig. 1-Sagami Bay, 25-55 m deep.

Material examined.

$33^{\circ} 23.4^{\prime} \mathrm{N}, 129^{\circ} 3.9^{\prime}$ E, $100 \mathrm{~m}$ deep; 1 ovig. ㅇ, ZLKU No. 13491; June 18, 1964 ; 1 . Yamashita leg.

Measurements.

Ovig. 우 (No. 13494) : Length of carapace, $4.2 \mathrm{~mm}$; breadth of carapace, $4.9 \mathrm{~mm}$.

Remarks. In the present specimen the epibranchial and median longitudinal ridges are not represented with granules but minute flat ones that thickly cover the entire surface. The ornamentation of the dorsal surface of the carapace is therefore closely related to that of $N$. sexangula Ihle from Timor Island, $34 \mathrm{~m}$ deep. In the present species, however, the front is truncated to be transverse, the anterolateral border of the carapace is trilobate indistinctly but more distinctly than in $N$. sexangula, each of the lateral angles of the carapace is obtuse, there is no angular projection just in front of the anterior end of each 
posterolateral lobe, and the merus of the cheliped is provided with two lobular prominences on its posterior border. The abdominal formula of the female is $2+R+T$ as in $N$. sexangula. It appears possible that it may come to be elevated to the specific rank.

Distribution. This species has previously been recorded from Sagami Bay and the west of Kyushu at the depths of 25 to $100 \mathrm{~m}$.

Genus Nursilia Bell, 1855

Nursilia dentata Bell, 1855

(Fig. 6)

Nursilia dentata Bell, 1855, p. 309, pl. 34, fig. 6-Indian Ocean.

Nursilia dentata, Has well, 1879, p. 56-Fitzray Is.

Nursilia dentata, Has well, 1882 , p. 128-No new locality.

Nursilia dentata, Miers, 1884, pp. 253, 548-Charimont, Qs., Aust., $20 \mathrm{~m}$ deep ; Arafra Sea, 60-65 m deep; Matuka, Fiji Is.; Seychelles, 10-20 m deep.

Nursilia dentata, Pocock, 1890, p. 73-South China Sea, $70 \mathrm{~m}$ deep.

Nursilia dentata, Alcock, 1896, p. 260-Andamans; off Ceylon, 55-60 m deep; Palk Str.; off Malabar coast, $45-55 \mathrm{~m}$ deep ; off Maldives, $35-55 \mathrm{~m}$ deep.

Nursilia dentata, Stimpson, 1907, p. 160-Between Katona-shima and Oushima, $20 \mathrm{~m}$ deep.

Nursilia dentata, Rathbun, 1911, p. 203, pl. 15, fig. 6-Seychelles and Cargados Carajos Is., $55-80 \mathrm{~m}$ deep.

Nursilia dentata, Ihle, 1918, p. 244-Java, Butung Str., Banda Sea, Sumbawa, Timor, Damar I. and Salawati I., 9-51 m deep.

Nursilia dentata, Sakai, 1937 , p. 122-No new locality.

Nursilia dentata, Kensley, 1969 , p. 162 , fig. $5-24^{\circ} 46^{\prime}$ S, $35^{\circ} 18^{\prime}$ E, $110 \mathrm{~m}$ deep.

\section{Material examined.}

$29^{\circ} 55.5^{\prime} \mathrm{N}, 127^{\circ} 22.9^{\prime} \mathrm{E}, 126 \mathrm{~m}$ deep; 1 juv., ZLKU No. 13504 ; December 5, 1967 ; H. Yamashita leg.

$31^{\circ} 19.5^{\prime} \mathrm{N}, 127^{\circ} 32^{\prime} \mathrm{E}, 126 \mathrm{~m}$ deep; 1 우, young, ZLKU No. 13505 ; June 17,$1964 ; \mathrm{H}$. Yamashita leg.

\section{Measurements.}

우 (No. 13505): Length of carapace, $5.4 \mathrm{~mm}$; breadth of carapace, $5.6 \mathrm{~mm}$.

Remarks. The present specimens are young, and unfortunately all the chelipeds and ambulatory legs are missing. The carapace is subcircular and convex, bearing several tubercles and some depressions. The gastric, cardiac and inner branchial regions are raised, but the surfaces along the lateral borders and also just inside each of the hepatic tubercles are deeply sunken. The lateral border of the carapace is thin, turned up and armed with four tubercles with knobbed gran. ules behind the generally convex hepatic margin. From the last tuber- 
cle a transverse sharp crest bordered with granules runs inwards to a tubercle at the antero-inner angle of the branchial region. The gastric region bears a tubercle at each side of the median, longitudinal low prominence. The cardiac margin is armed with three tubercles, one in the middle and one each side of the median one, which are united with a strong carina. Of the cardiac tubercles the median one is the most prominent, and curved forwards, while the lateral ones are weakly directed outwards.

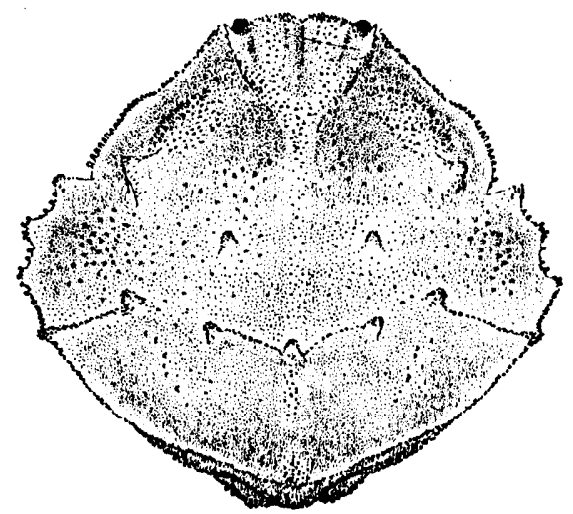

Fig. 6. Nursilia dentata Bell, young 우, $5.4 \times 5.6 \mathrm{~mm}$.

The species has previously been included in the fauna of Japan on authority of Stimpson based on the material from the northern Ryukyu Islands. The identity of the Japanese materials with those from the South Pacific and the Indian Ocean is, however, not quite sure due to somewhat different formation of the front and lateral borders of the carapace and the ornamentation of the dorsal surface. In the present young specimens the lateral angles of the front are not extended forwards, so that the front is almost truncated, and the hepatic mar. gin is only weakly convex without a prominent tooth. In addition, the lateral cardiac tubercles are prominent, but there is no tubercle behind the median cardiac tubercle, and also the intestinal region is not armed with a tubercle. Those differences enumerated appear to be important, but the specimens are, as mentioned elsewhere, young without the chelipeds and ambulatory legs. Therefore, the comparison of the young specimens of the other localities with the present specimens, and also the examination of the large specimens from the Jap. anese waters are very desirable for confirmation of the identification.

Distribution. This species is known from both the Pacific and the Indian Oceans. It ranges from southern Japan southwards to the Fiji Islands and northern Australia, and westwards to the Seychelles. The bathymetric range is from about 7 to $70 \mathrm{~m}$.

Genus Arcania Leach, 1817

\section{Arcania undecimspinosa de Haan, 1841}


Arcania undecimspinosa, Bell, 1855, p. 309-No new locality.

Arcania granulosa Miers, 1877, p. 240, pl. 38, fig. 29-Moreton Bay, Qs., Aust.

Arcania granulosa, Haswell, 1879, p. 58-No new locality.

Arcania granulosa, Haswell, 1882, p. 131-No new locality.

Arcania undecimspinosa, Miers, 1884, p. 548-Seychelles, 7-20 m deep.

Arcania undecimspinosa, Walker, 1878, p. 111-Singapore.

Arcania undecimspinosa, Ortmann, 1892, p. 577-Tokyo Bay and Kagoshima.

Arcania undecimspinosa, Henderson, 1893, p. 404-Gulf of Martaban.

Arcania undecimspinosa, Alcock, 1896, p. 266-Andamans and Palk Strait.

Arcania undecimspinosa, Rathbun, 1902, p. 30-Kii and Nagasaki.

Arcania undecimspinosa, Rathbun, 1910, p. 314-Gulf of Siam, $9 \mathrm{~m}$ deep.

Arcania undecimspinosa, Parisi, 1914, p. 296-Tokyo Bay, Sagami Bay and China Sea. Arcania undecimspinosa, Ihle, 1918, p. 265-Sulu Sea, $14 \mathrm{~m}$ deep.

Arcania undecimspinosa, Balss, 1922, p. 132-Sagami Bay and Inland Sea of Japan, $180 \mathrm{~m}$ deep.

Arcania undecimspinosa, Yokoya, 1933, p. 132-Suruga Bay. Kii, Goto Is., east of Cheju Do I. and near Wakasa Bay, 64-219 $\mathrm{m}$ deep.

Arcania undecimspinosa, Sakai, 1934, p. 288-Nagasaki.

Arcania undecimspinosa, Sakai, 1936, p. 58, pl. 10, fig. 1-Japan.

Arcania undecimspinosa, Sakai, 1937, p. 123, fig. 15, a, pl. 14, fig. 2-Tokyo Bay, Sagami Bay, Shimoda, Kii and Tosa Bay.

Arcania undecimspinosa, Miyake, 1961, p. 11-Amakusa Sea.

Arcania undecimspinosa, Miyake, 1961a, p. 170-Sea of Ariaké.

Arcania undecimspinosa, Sakai, 1965, p. 40, fig. 6, a, pl. 16, fig. 3-Sagami Bay, 35-65 m deep.

Material examined.

East China Sea without definite locality; $1 \hat{0}$, ZLKU No. 292; August 1953; H. Maéda leg.

Measurements.

$\sigma$ (No. 292): Length of carapace in median line excluding postero-dorsal spine, $26.8 \mathrm{~mm}$; the same including frontal lateral angles and posterolateral teeth, $31.3 \mathrm{~mm}$; breadth of carapace excluding lateral spines, $24.6 \mathrm{~mm}$; the same including lateral spines, $31.0 \mathrm{~mm}$.

Distribution. This species ranges from Japan southwards to Moreton Bay, Queensland, and westwards to the Seychelles. In the Japanese waters it is known from Tokyo Bay southwards to the west of Kyushu, and from the Goto Islands and east of Cheju Do Island northwards to off Kyo-gasaki, near Wakasa Bay. Its bathymetric range is from about $7 \mathrm{~m}$ in the Seychelles to $219 \mathrm{~m}$ in Japan.

\section{Arcania globata Stimpson, 1858}

Arcania globata, Stimpson, 1907, p. 156, pl. 18, fig. 9-South China Sea near Hong- 
kong, and North China Sea in $23^{\circ} \mathrm{N}, 30-45 \mathrm{~m}$ deep.

Arcania globata, Miers, 1879, p. 44-North of Cheju Do I., $45 \mathrm{~m}$ deep.

Arcania globata, de Man, 1907, p. 400, pl. 31, figs. 11-13-Inland Sea of Japan.

Arcania globata, Balss, 1922, p. 132-Sagami Bay, 130-150 m deep.

Arcania globata, Yokoya, 1933, p. 134-Suruga Bay, Kii, north of Kyushu and off

Yamaguchi Pref., 46-93 m deep.

Arcania globata, Sakai, 1934, p. 288-Nagasaki.

Arcania globata, Sakai, 1936, p. 57, pl. 10, fig. 3-Japan.

Arcania globata, Sakai, 1937, p. 125, fig. 17-Sagami Bay, Shimoda, Ise Bay and Kii.

Arcania globata, Miyake, 1961, p. 14-Amakusa Sea.

Arcania globata, Miyake, 1961a, p. 170-Sea of Ariaké.

Arcania globata, Sakai, 1965, p. 41, pl, 16, fig. 4-Sagami Bay, 35-55 m deep.

Material examined.

$31^{\circ} 19.5^{\prime} \mathrm{N}, 127^{\circ} 32^{\prime}$ E, $126 \mathrm{~m}$ deep ; 1 juv., ZLKU No. 13506 ; June 17, 1967 ; H. Yamashita leg.

Distribution. This species is restricted to the West Pacific from Japan to the South China Sea near Hongkong. In Japan it ranges from Sagami Bay to the west of Kyushu and from the north of Kyushu to Wakasa Bay. The bathymetric range is from 30 to $150 \mathrm{~m}$.

\section{Genus Randallia Stimpson, 1857 \\ Randallia eburnea Alcock, 1896}

Randallia eburnea Alcock, 1896, p. 197-Off Laccadive Is., $55 \mathrm{~m}$ deep.

Randallia eburnea, Illust. Zool. Invest., Crust., 1896, pl. 30, fig. 4.

Randallia eburnea, Ihle, 1918, p. 246-Molo Str., Waigen I. and near Butung I., 54-94 m deep.

Randallia japonica Yokoya, 1933, p. 130, fig. 46-Suruga Bay, south of Omaé-zaki, Goto Is., Tsu-shima I., north of Kyushu, off Yamaguchi Pref., 62-210 m deep.

Randallia eburnea, Sakai 1934, p. 289, pl. 18, fig. 4-Shimoda.

Randallia eburnea, Sakai, 1936, p. 54, pl. 9, fig. 3-Japan.

Randallia eburnea, Sakai, 1937, p. 132, fig. 22-Sagami Bay.

Randallia eburnea, Tyndale-Biscoe and George, 1962, p. 87, fig. 7,7-Shark Bay, W. Aust., $85 \mathrm{~m}$ deep.

Randallia eburnea, Sakai, 1965, p. 42, pl. 17, fig. 1-Sagami Bay, 35-85 m deep.

Material examined.

$27^{\circ} 55^{\prime} \mathrm{N}, 123^{\circ} 35^{\prime}$ E ; $2 \mho^{\circ} \sigma^{\circ}, 1$ ovig. 우, 2 우우, ZLKU No. 13507 ; April 9, 1962 ; H. Yamashita leg.

$29^{\circ} 55.5^{\prime} \mathrm{N}, 127^{\circ} 22.9^{\prime} \mathrm{E}, 126 \mathrm{~m}$ deep ; 6 juv., ZLKU No. 13512 ; December 5,1967 ; H. Yamashita leg.

Measurements.

$\circlearrowleft$ (No. 13507-1): Length of carapace, $13.4 \mathrm{~mm}$; breadth of carapace, 
$13.3 \mathrm{~mm}$

Ovig. ㅇ (No. 13507-3) : Length of carapace, $13.0 \mathrm{~mm}$; breadth of carapace, $13.5 \mathrm{~mm}$.

Distribution. This species is rather widely distributed in the IndoWest Pacific waters, ranging from Japan through the West Pacific to off the Laccadive Islands. In Japan it is known from Sagami Bay to the west of Kyushu and also to off Yamaguchi Prefecture. Its bathymetric range is from 35 to $210 \mathrm{~m}$.

Genus Myra Leach, 1817

Myra fugax (Fabricius, 1798)

Myra fugax, de Haan, 1841, p. 134, pl. 33, fig. 1-Japan.

Myra carinata Bell, 1855, p. 297, pl. 32, fig. 3-Philippines.

Myra fugax, Alcock, 1896, p. 202 (lit.)-India, Andamans and Persian Gulf.

Persephona Sugax, Rathbun, 1902, p. 30-Kii and Nagasaki.

Myra fugax, Parisi, 1914, p. 295-Sagami Bay and Suruga Bay.

Myra fugax, Ihle, 1918, p. 256-Madura Str., Lombok, Bima, Flores and Kei Is., 22$56 \mathrm{~m}$ deep.

Myra fugax, Balss, 1922, p. 127-Sagami Bay and Nagasaki, 10-180 m deep.

Myra fugax, Rathbun, 1924, p. 26-Cape Jaubert, W. Aust., $15 \mathrm{~m}$ deep.

Myra fugax, Monod, 1930, p. 140, fig. 8-Palastin coast, 40-50 m deep.

Myra fugax, Yokoya, 1933, p. 126-Northern Japan Sea.

Myra fugax, Sakai, 1937, p. 134, pl.14, fig. 5-Tateyama Bay, Sagami Bay, Shimoda,

Ise Bay, Kii and Nagasaki.

Myra fugax, Buitendijk, 1939, p. 229-Timor, 10-15 m deep.

Myra fugax, Stephensen, 1945, p. 72, fig. 7, B, C-Persian Gulf, 5.5-83 m deep.

Myra fugax, Barnard, 1950, p. 373, fig. 71, d, e-Delagoa Bay.

Myra fugax, Serène, 1955, p. 182, figs. $7,{ }_{1-3}$ pl. 7 (lit.)-Viet Nam.

Myra fugax, Miyake, 1961, p. 14-Amakusa Sea.

Myra fugax, Miyake, 1961a, p. 170-Sea of Ariaké.

Myra fugax, Sakai, 1965, p. 43, pl. 17, fig. 3-Sagami Bay, 30-50 m deep.

Material examined.

East China Sea without definite locality; 1 ㅇ, damaged, ZLKU No. 13518; October

10, 1962; H. Yamashita leg.

Distribution. This species bears a wide range in the Indo-West Pacific waters from Japan to New Caledonia and to northern Western Australia, and westwards to South Africa and the Red Sea. It is peculiar that it also extends the range to the east Mediterranean through the Suez Canal. In Japan it is rather commonly found from Sagami Bay southwards to the west of Kyushu, and also occurs in the northern Sea of Japan. 


\section{Genus Pariphiculus Alcock, 1896 \\ Pariphiculus coronatus (Alcock et Anderson, 1894)}

Randallia coronata Alcock and Anderson, 1894, p. 177-Bay of Bengal off Coromandel coast, India, $200 \mathrm{~m}$ deep.

Pariphiculus coronatus, Alcock, 1896, p. 258-No new locality.

Pariphiculus coronatus, Illust. Zool. Invest., Crust., 1896, pl. 24, fig. 2.

Pariphiculus coronatus, Doflein, 1904, p. 41, pl. 14, fig. 7-Near Great Nicobar I., $296 \mathrm{~m}$ deep.

Pariphiculus coronatus, Balss, 1915, p. 14-Red Sea, $800 \mathrm{~m}$ deep.

Pariphiculus coronatus, Ihle, 1918, p. 249-Sumbawa, $274 \mathrm{~m}$ deep.

Pariphiculus coronatus, Balss, 1922, p. 131-Tokyo Bay and Sagami Bay, $150 \mathrm{~m}$ deep. Pariphiculus coronatus, Yokoya, 1933, p. 129, fig. 45-Sagami Bay, south-east of Omaézaki, Bungo Str. and Tsu-shima Str., 135-214 $\mathrm{m}$ deep.

Pariphiculus coronatus, Sakai, 1936, p. 56, fig. 17-Japan.

Pariphiculus coronatus, Sakai, 1937, p. 129, pl. 14, fig. 6-Sagami Bay.

Pariphiculus coronatus, Sakai, 1965, p. 43, pl. 17, fig. 5-Sagami Bay, 65-85 m deep.

Material examined.

$32^{\circ} 0.6^{\prime} \mathrm{N}, 127^{\circ} 12^{\prime} \mathrm{E}, 120 \mathrm{~m}$ deep ; $1 \sigma^{\prime}$, damaged, ZLKU No. 13519 ; June 17,$1964 ; \mathrm{H}$. Yamashita leg.

Distribution. This species is known from Japan, Sumbawa, Great Nicobar Island, the Bay of Bengal off Coromandel coast and the Red Sea. In Japan it ranges from Tokyo Bay to the Tsu-shima Strait and East China Sea along the Pacific coast. It is remarkable that the bathymetric range is from $65 \mathrm{~m}$ in Sagami Bay to $800 \mathrm{~m}$ in the Red Sea.

Genus Ixoides MacGilchrist, 1905

Ixoides cornutus MacGilchrist, 1905

Ixoides cornutus MacGilchrist, 1905, p. 255-Persian Gulf, $95 \mathrm{~m}$ deep.

Ixoides cornutus, Illust, Zool. Invest., Crust., 1905, pl. 73, fig. 2.

Ixoides cornutus?, Gordon, 1931, p. 530, fig. 7-Hongkong.

Ixoides cornutus, Sakai, 1937, p. 137, pl. 19-Kii and Tosa Bay.

Ixoides cornutus, Stephensen, 1945, p. 74-No new locality.

Ixoides cornutus, Sakai, 1965, p. 44, pl, 18, fig. 3-Sagami Bay.

Material examined.

East China Sea without definite locality; 1 우 ZLKU No. 13520; April 7, $1962 ; \mathrm{H}$. Yamashita leg.

Off Chilung, Taiwan; $1 \precsim$. ZLKU No. 13358; November 1966; Taiwan Mar. Res. Inst. leg., received though Mr. H. P. Yu. 


\section{Measurements.}

$\sigma$ (No. 13358): Length of carapace in median line including frontal lateral angle, $21.4 \mathrm{~mm}$; the same including posterolateral outgrowths, $23.1 \mathrm{~mm}$; breadth of carapace excluding lateral processes, $24.4 \mathrm{~mm}$; the same including lateral processes, $33.1 \mathrm{~mm}$.

o (No. 13520): Length of carapace in median line including frontal lateral angle, $31.4 \mathrm{~mm}$; the same including posterolateral outgrowths, $35.4 \mathrm{~mm}$; breadth of carapace excluding lateral processes, $38 \mathrm{~mm}$; the same including lateral processes, $55.3 \mathrm{~mm}$.

Distribution. This species is known from Japan, Hongkong and the Persian Gulf. In Japan it has previously recorded from Sagami Bay, the Kii province and Tosa Bay.

\section{Genus Cryptocnemus Stimpson, 1858}

\section{Cryptocnemus obolus Ortmann, 1892}

Cryptocnemus obolus Ortmann, 1892, p. 576, pl. 26, fig. 12-Sagami Bay, $180 \mathrm{~m}$ deep. Cryptocnemus obolus, Ihle, 1918, p. 286-Sulu Is., $275 \mathrm{~m}$ deep.

Cryptocnemus obolus, Yokoya, 1933, p. 117, fig. 40-Bungo Str. and east of Ariaké Bay, 181-190 m deep.

Cryptocnemus obolus, Sakai, 1936, p. 59, fig. 20-Japan.

Cryptocnemus obolus, Sakai, 1937, p. 140, fig. 25-Sagami Bay and off Mie Pref.

Cryptocnemus obolus, Sakai, 1965, p. 45, pl. 18, fig. 2-Sagami Bay, 80-120 m deep.

Material examined.

$27^{\circ} 14.5^{\prime} \mathrm{N}, 124^{\circ} 45^{\prime} \mathrm{E}, 98 \mathrm{~m}$ deep ; $1 \mathrm{\delta}^{\star}, \mathrm{ZLKU}$ No. 13521 ; June 12,1962 ; H. Yamashita leg.

$27^{\circ} 55^{\prime} \mathrm{N}, 123^{\circ} 35^{\prime} \mathrm{E} ; 10^{\star}, 1$ ovig. 오, 1 ㅇ. ZLKU No. 13522; April 9, 1962; H. Yamashita leg.

$29^{\circ} 55.5^{\prime} \mathrm{N}, 127^{\circ} 22.9^{\prime} \mathrm{E}, 126 \mathrm{~m}$ deep; $1 \sigma^{7}$, ZLKU No. 13525; December 5, 1967; H. Yamashita leg.

Measurements.

उð(No. 13521 and 13525): Length of carapace including frontal teeth, 6.0 and $5.4 \mathrm{~mm}$; breadth of carapace, 6.2 and $5.7 \mathrm{~mm}$.

Ovig. + (No. 13522-2): Length of carapace including frontal teeth, $5.9 \mathrm{~mm}$; breadth of carapace, $6.4 \mathrm{~mm}$.

우 (No. 13522-3): Length of carapace including frontal teeth, $5.7 \mathrm{~mm}$; breadth of carapace, $6.2 \mathrm{~mm}$.

Distribution. This species occurs in the Japanese waters and Sulu Islands at the depths of 80 to $275 \mathrm{~m}$. In Japan it ranges from Sagami Bay to the east of Kagoshima Prefecture, and to the East China Sea as recorded at present. 


\section{Genus Leucosia Weber, 1795}

\section{Leucosia obtusifrons de Haan, 1841}

Leucosia obtusifrons de Haan, 1841, p. 133, pl. 33, fig. 2-Japan.

Leucosia obtusifrons, Bell, 1855, p. 284-Japan.

Leucosia obtusifrons, Ortmann, 1892, p. 585-Tokyo Bay.

Leucosia obtusifrons, Alcock, 1896, p. 216-Coromandel coast, India.

Leucosia obtusifrons, Doflein, 1902, p. 654-Sagami Bay.

Leucosia obtusifrons, Laurie, 1906, p. 362-Gulf of Manaar and off Kaltura, Ceylon.

Leucosia obtusifrons, Parisi, 1914, p. 291, pl. 13, fig. 4-Sagami Bay.

Leucosia obtusifrons, Bals8, 1922, p. 128-Uraga Str. and Sagami Bay, 150-300 m deep. Leucosia obtusifrons, Yokoya, 1933, p. 127-Sagami Bay, Suruga Bay, Kii Str., Bungo

Str., Kagoshima Pref., Koshiki-jima Is., Goto Is., Tsu-shima Str., east of Cheju

Do I. and off Yamaguchi Pref., 62-203 $\mathrm{m}$ deep.

Leucosia obtusifrons, Sakai, 1934, p. 285-Nagasaki.

Leucosia obtusifrons, Sakai, 1936, p. 60, fig. 21, pl. 11, fig. 2-Japan.

Leucosia obtusifrons, Sakai, 1937, p. 145, figs. 26, d, 28, a, pl. 15, fig. 3-Sagami Bay and $\mathrm{Kii}$.

Leucosia obtusifrons, Miyake, 1961, p. 14-No new locality.

Leucosia obtusifrons, Sakai, 1965, p. 46, pl. 18, figs, 5, 6-Sagami Bay, 35-80 m deep.

Material examined.

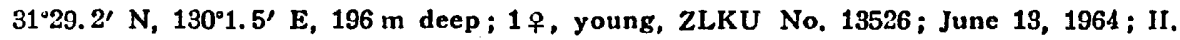
Yamashita leg.

Measurements.

우 (No. 13526): Length of carapace, $6.0 \mathrm{~mm}$; breadth of carapace, $5.6 \mathrm{~mm}$.

Distribution. This species is known from the Japanese waters and off coasts of India and Ceylon. In Japan it is commonly found from Sagami Bay southwards to the west of Kyushu, and the Tsushima Strait to off Yamaguchi Prefecture. The bathymetric range is from 35 to $300 \mathrm{~m}$.

\section{Leucosia unidentata de Haan, 1841}

Leucosia unidentata de Haan, 1841, p. 133, pl. 33, fig. 3-Japan and Moluccas.

Leucosia unidentata, Bell, 1855, p. 284-No definite locality.

Leucosia unidentata, Haswell, 1879, p. 44-Torres Strait.

Leucosia unidentata, Haswell, 1882, p. 118-No new locality.

Leucosia obtusifrons var. unidentata, Ortmann, 1892, p. 585-Tokyo Bay.

Leucosia unidentata, Alcock, 1896, p. 215-Off Malabar coast, India, $80 \mathrm{~m}$ deep and

Hongkong.

Leucosia unidentata, Parisi, 1914, p. 292, pl. 13, fig. 3-Sagami Bay.

Leucosia obtusifrons unidentata, Balss, 1922, p. 128-Sagami Bay.

Leucosia obtusifrons unidentata, Sakai, 1934, p. 285-Nagasaki. 
Leucosia unidentata, Sakai, 1936, p. 60, fig. 22, pl. 11, fig. 3-Japan.

Leucosia unidentata, Sakai, 1937, p. 146, figs. 26, c, 28, b, pl. 15, fig. 4-Sagami Bay, Shimoda and Kii.

Leucosia unidentata, Miyake, 1961, p. 15-No new locality.

Leucosia unidentata, Sakai, 1965, p. 47, pl. 19, fig, 3-Sagami Bay, 35-65 m deep.

Material examined.

$27^{\circ} 14.5^{\prime} \mathrm{N}, 124^{\circ} 45^{\prime} \mathrm{E}$; 1 우, young, ZLKU No. 13527 ; June 12, 1962 ; H. Y amashita leg.

Measurements.

ㅇ (No. 13527): Length of carapace, $5.7 \mathrm{~mm}$; breadth of carapace, $4.9 \mathrm{~mm}$.

Distribution. This species ranges from Japan through the Moluccas to the Torres Strait, and westwards to the Malabar coast. India. In the Japanese waters it is known from Sagami Bay, the Kii 'province, Nagasaki and the East China Sea recorded at present. Its bathymetric range is from 35 to $80 \mathrm{~m}$.

\section{Genus Philyra Leach, 1817}

\section{Philyra heterograna Ortmann, 1892}

Philyra heterograna Ortmann, 1892, p, 582, pl. 26, fig. 17-Tokyo Bay.

Philyra peitaihoensis Shen, 1932, p. 18, figs. 10-12, pl.1, figs. 1, 2-Peichihli Bay and Shantung Penin., North China.

Philyra heterograna, Sakai, 1937, p. 158, fig. 33-Sagami Bay and Inland Sea of Japan. Philyra heterograna, Miyake, 1961a, p. 171-Sea of Ariaké.

Material examined.

$32^{\circ} 30.2^{\prime} \mathrm{N}, 123^{\circ} 2^{\prime}$ E, $34 \mathrm{~m}$ deep; $1 \delta^{\prime}$, ZLKU No. 13528; March 16, 1963 ; H. Yamashita leg.

\section{Measurements.}

$\circlearrowleft$ (No. 13528): Length of carapace, $9.0 \mathrm{~mm}$; breadth of carapace, $9.1 \mathrm{~mm}$.

Distribution. This species has hitherto been recorded from Tokyo Bay, Sagami Bay, the Inland Sea and the Sea of Ariake as Ph. heterograna, and Peichihli Bay and the Shantung Peninsula, North China as $P h$. peitaihoensis. The bathymetric range has not previously been recorded. 


\section{Family Calappidae \\ Genus Matuta Weber, 1795 \\ Matuta curtispina Sakai, 1961}

Matuta curtispina Sakai, 1961, p. 139, pl. 3, fig. 7-Off Aichi Pref.

Matuta curtispina, Sakai, 1965, p. 60, pl. 24, fig. 2-Sagami Bay, and off Aichi Pref., 35-80 $\mathrm{m}$ deep.

\section{Material examined.}

$26^{\circ} 5^{\prime} \mathrm{N}, 122^{\circ} 55^{\prime}$ E-26 $6^{\circ} .8^{\prime} \mathrm{N}, 123^{\circ} 1.9^{\prime}$ E, 110-111 $\mathrm{m}$ deep; $1 \sigma^{\text {t’ }}$, young, ZLKU No. 13529 ; December 9, 1967 ; H. Yamashita leg.

\section{Measurements.}

o(No. 13529): Length of carapace, $6.7 \mathrm{~mm}$; breadth of carapace including lateral teeth, $7.4 \mathrm{~mm}$.

Distribution. This species has previously been known only from Sagami Bay and off Aichi Prefecture at the depths of 35 to $80 \mathrm{~m}$.

\section{Acknowledgements}

The authors' cordial thanks are due to Mr. Hideo Yamashita of Seikai Regional Fisheries Research Laboratory for providing them with many valuable specimens upon which this paper is mainly based. The authors thank also Dr. Tadashige Habe, Dr. Minoru Imajima and Dr. Sadao Kosuge who kindly made available the materials from the sea around Tsu-shima Island collected by the research vessel Genkai for the trustees of the National Science Museum, Tokyo. The senior author must express his hearty thanks to Dr. Tune Sakai for the kind guidance.

\section{Literature}

Adams, $\Lambda$. and A. White, 1848. Crustacea, The zoology of II.M.S. "Samarang." London, i-viii, 1-66, pls. 1-13.

Alcock, A., 1894. Natural history notes from H.M. Indian marine survey steamer "Investigator." Ser. 2, no. 1. On the results of the deep-sea dredging during the season 1890-91. Ann. Mag. nat. Hist., ser. 6, 13: 225-245, 321-334, 400-411.

Alcock, A., 1896. Materials for a carcinological fauna of India. No. 2. The Brachyura Oxystomata. J. Asiat. Soc. Bengal, 65 : 134-296, pls. 6-8.

Alcock, A., 1899. Natural history notes from the royal Indian marine survey ship "Investigator," Commander T. H. Heming, R. N. commanding. Ser. 3, no. 3. On some notable and rare species of Crustacea. Ibid., 68: 111-119.

Alcock, A., 1899a. Materials for a carcinological fauna of India. No. 5. Brachyura Primigenia or Dromiacea. Ibid., 68: 123-169. 
Alcock, A. \& A. R. Anderson, 1894. Natural history notes from H. M. Indian marine survey steamer "Investigator." Ser. 2 , no. 14. An account of a recent collection of deep-sea Crustacea from the Bay of Bengal and Laccadive Sea. Ibid., 63: 141-185, pl. 9.

Balss, H., 1915. Die Decapoden des Roten Meeres. II. Anomuren, Dromiaceen und Oxystomen. Expeditionen S. M. Schiff "Pola" in das Rote Meer nördliche und südliche Hälfte 1895/96-1897/98. Zoologische Ergebnisse XXXI. Denkschr. Akad. Wiss. Wien, math.-nat. K1., 92 : 1-20.

Balss, H., 1921. Diagnosen neuer Decapoden aus dem Sammlungen der Deutschen Tiefsee-Expedition und der japonischen Ausbeute Dofleins und Haberers. Zool. Anz., 52: 175-178.

Balss, H., 1922. Ostasiatische Decapoden. III. Die Dromiaceen, Oxystomen und Parthenopiden. Arch. Naturg., ser. A, 88: 104-140.

Barnard, K. H., 1946. Descriptions of new species of South $\Lambda$ frican decapod Crustacea with notes on synonymy and new records. Ann. Mag. nat. Hist., ser. 11, $13: 361-392$.

Barnard, K. H., 1950. Descriptive catalogue of South African decapod Crustacea. Ann. S. Afr. Mus., 38: 1-837.

Bell, T., 1855. Horae carcinologicae, or Notices of Crustacea. I. A monograph of the Leucosiadae, with observations on the relations, structure, habits and distribution of the family; a revision of the generic characters; and descriptions of new genera and species. Trans. Linn. Soc. London, $21: 277-314$, pls. 30-34.

Bennett, E. W., 1964. Marine fauna of New Zealand: Crustacea Brachyura. N. Z. Dep. sci. industr. Res. Bull., 153: 1-120.

Buitendijk, A. M., 1939. The Dromiacea, Oxystomata and Oxyrhyncha of the Snellius Expedition. Temminckia, 4: 223-276, pls. 7-11.

Chopra, B., 1934. Further notes on Crustacea Decapoda in the Indian Museum. VI. On a new dromiid and a rare oxystomous crab from the Sandheads, off the mouth of the Hooghly River. Rec. Ind. Mus., 36: 477-481, pl. 8.

Dell, R. K., 1968. Notes on New Zealand crabs. Rec. Dominion Mus., 6: 13-28.

Doflein, F., 1902. Ostasiatische Decapoden. Abh. K. B. Akad. Wiss., II Cl., 21 ; 611-670, pls. 1-6.

Doflein, F., 1904. Brachyura, Wiss. Ergebn, Deutsch. Tiefsee-Exped. "Valdivia." Jena, 6: i-xiv, 1-314.-Atlas, pls. 1-58.

Edmondson, C. H., 1935. New and rare Polynesian Crustacea. Occ. Pap. Bernice P. Bishop Mus., 10 (24): 1-40, pls. $1,2$.

Gordon, I., 1931. Brachyura from the coasts of China. J. Linn. Soc. London, Zool., 37 : 525-558.

Gordon, I., 1950. Crustacea Dromiacea. I. Systematic account of the Dromiacea collected by the "John Murray" Expedition. IT. The morphology of the spermatheca in certain Dromiacea. Sci. Rep. John Murray Exp. 1933-1934, 9: 201-253.

Gordon, I., 1963. On the relationship of Dromiacea, Tymolinae and Raninidae to the Brachyura. In: Phylogeny and evelution of Crustacea. Mus. Comp. Zool., spec. publ., 51-57.

Grant, F. E., 1905. Crustacea dredged off Port Jackson in deep water. Proc. Linn. Soc. N.S.W., 30: 312-324, pls. 10, 11.

Haan, W. de, 1833-1849. Crustacea. In: Fauna Japonica sive descriptio animalium, quae in itinere per Japoniam, jussu et auspiciis superiorum, qui summum in India Vatava Imperium tenent, suscepto, annis 1823-1830 collegit, notis, observa- 
tionibus et abumbrationibus illustravit. i-xvii, i-xxxi, 1-241, pls. 1-244, pls. 1-55, $A-Q, 1,2$.

Ilale, H. M., 1927. The crustaceans of South Australia. Adelaide, 1-201.

Ilaswell, W. A., 1879. Contributions to a monograph of Australian Leucosiidae. Proc. Linn. Soc. N.S.W., 4: 44-60, pls. 5, 6.

Haswell, W. A., 1882. Catalogue of the Australian stalk- and sessile-eyed Crustacea. Sydney, 1-324, addenda and corrigenda, pls. 1-4.

Henderson, J. R., 1888. Report on the Anomura collected by H.M.S. Challenger during the years 1873-76. Rep. sci. Res. Voy. H. M. S. Challenger, Zool., 27 : i-xi, 1-221, pls. 1-21.

Henderson, J. R., 1893. A contribution to Indian carcinology. Trans. Linn. Soc. London, ser. 2, Zool., 5 : 325-458, pls. 36-40.

Ihle, J. E. W., 1913. Die Decapoda Brachyura der Siboga-Expedition. I. Dromiacea. Siboga-Exped., Monogr., 39b : 1-96, pls. 1-4.

Ihle, J. E. W., 1918. Ditto. III. Oxystomata: Calappidae, Leucosiidae, Raninidae. Ibid., 39b ${ }^{2}: 155-322$.

Illustration of the zoology of the royal Indian marine survey ship Investigator, under the command of Commander T. H. Heming, R. N. Crustacea, 1896-1907, pls. 1-79.

Kensley, B. F., 1969. Decapod Crustacea from the south-west Indian Ocean. Ann. S. Afr. Mus., 52 : 149-181.

Kim, H. S., 1966. Unrecorded species of brachyuran decapods from Korea. Sung Kyun Kwan Univ. J., 11: 399-409, pls. 1-3 (in Korean with English summary).

Laurie, R. D., 1906. Report on the Brachyura collected by Professor Herdman, at Ceylon, in 1902. Ceylon Pearl Oyster Fish. Rep., 5, suppl. rep., $40: 349-432$, pls. $1,2$.

MacGilchrist, A. C., 1905. Natural history notes from the R.I.M.S. "Investigator," Capt. T. H. Heming, R. N. (retired), commanding. Ser. 3, no. 6. An account of the new and some of the rarer decapod Crustacea obtained during the sureying seasons 1901-1904. Ann. Mag. nat. Hist., ser. 7, 15: 233-268.

Man, J. G. de, 1907. On a collection of Crustacea, Decapoda and Stomatopoda chiefly from the Inland Sea of Japan, with description of new species. Trans. Linn. Soc. London, ser. 2, Zool., 9: 325-458, pls. 36-40.

Miers, J. E., 1877. Notes upon the oxystomous Crustacea. Trans. Linn. Soc. London, ser. 2, Zool., 1 : 235-249, pls. 38-40.

Miers, J. E., 1879. On Crustacea from the Corean and Japanese Sea. Proc. zool. Soc. London, 1879 : 18-61, pls. 1-3.

Miers, J. E., 1884. Crustacea. Report on the zoological collection in the Indo-Pacific Ocean during the voyage of H.M.S. "Alert" 1881-1882. London, 178-322, 513-575, pls. 18-34.

Miers, J. E., 1886. Report on the Brachyura collected by H.M.S. Challenger during 1873-1876. Rep. sci. Res. Voy. H.M.S. Challenger, Zool., 17 : i-1, 1-362, pls. 1-29.

Milne Edwards, A., 1873. Description de quelques crustacés nouveaux ou peu connus provenant du Musée de M. C. Godeffroy. J. Mus. Godeffroy, $1: 253-264$, pls. 1,2 .

Miyake, S., 1961. Fauna and flora of the sea around the Amakusa Marine Biological Laboratory. Part II. Decapod Crustacea. Amakusa Mar. Biol. Lab. Kyushu Univ., i-iv, 1-30 (in Japanese). 
Miyake, S., 1961a. $\Lambda$ list of the decapod Crustacea of the Sea of Ariaké, Kyushu. Rec. oceanogr. Wks. Japan, spec. $5: 165-178$.

Monod, Th., 1930. Ueber einige indo-pazifische Decapoden der Meeresfauna Syriens. Zool. Anz., $92:$ 135-141.

Ortmann, A., 1892. Die Decapoden-Krebse des Strassburger Museums, mit besonderer Berücksichtigung der von Herrn Dr. Döderlein bei Japan und bei den Liu-KiuInseln gesammelten und z.Z. im Strassburger Museum aufbewahrten Formen. V. Die Abtheilungen Hippidea, Dromiidea and Oxystomata. Zool. Jahrb., Syst., $6: 532-586, \mathrm{pl}, 26$.

Parisi, B., 1914. I decapodi giapponesi del Museo di Milano. 1. Oxystomata. Atti Soc. Ital. Sci. nat., $53: 282-312$, pls. 11-13.

Parisi, B., 1915. Ditto. 2. Dromiacea. Ibid., 54 : 102-116, pls. 2, 3.

Pocock, R. I., 1890. Report upon the Crustacea collected by P. W. Bassett-Smith, during the survey of the Macclesfield and Tizard Banks, in the China Sea, by H.M.S. "Rambler." Ann. Mag. nat. Hist., ser. 6, 5: 72-80.

Rathbun, M. J., 1902. Japanese stalk-eyed crustaceans, Proc. U. S. Nat. Mus., 26 : 23-55.

Rathbun, M. J., 1906. The Brachyura and Macrura of the Hawaiian Islands. U. S. Fish Comm. Bull, for 1903, 23: 827-930, pls, 1-24.

Rathbun, M. J., 1910. The Danish Expedition to Siam, 1899-1900. V. Brachyura. K. 1). Vid. Selsk. Skr., sér. 7, 5: 301-367, pls, 1, 2.

Rathbun, M. J., 1911. The Percy Sladen Trust Expedition to the Indian Ocean in 1905. 3 (11). Marine Brachyura. Trans. Linn. Soc. London, ser. 2, Zool., 14 : 191-261, pls. 15-20.

Rathbun, M. J., 1923. Report on the crabs obtained by the F.I.S. "Endeavour" on the coasts of Qucensland, New South Wales, Victoria, South Australia and Tasmania. Report on the Brachyrhyncha, Oxystomata and Dromiacea. Biol. Res. "Endeavour," 5: 95-156, pls. 16-42.

Rathbun, M. J., 1924. Brachyura, Albuneidae and Porcellanidae from Mjöbergs Swedish Scientific Expedition to Australia. Ark. Zool., 16:1-33, pl. 1.

Rathbun, M. J., 1932. Preliminary descriptions of new species of Japanese crabs. Proc. biol. Soc. Wash., $45: 28-38$.

Sakai, T., 1934. Brachyura from the coast of Kyushu, Japan. Sci. Rep, Tokyo Bunrika Daigaku, sec. B, 1:281-330, pls. 17, 18.

Sakai, T., 1935. New or rare species of Brachyura, collected by the "Misago" during the zoological survey around the Izu-Peninsula. Ibid., $2: 63-88$, pls. 6-8.

Sakai, T., 1936. Crabs of Japan. 66 plates in life coloures with descriptions. Tokyo 1-239, 1-12, pls, 1-66, frontispiece (in Japanese).

Sakai, T., 1936a. Studies on the crabs of Japan. I. Dromiacea. Sci. Rep. Tokyo. Bunrika Daigaku, sec. B, 3, suppl. 1: 1-66, pls. 1-9.

Sakai, T., 1937. Ditto. II. Oxystomata. Ibid., $2: 67-192$, pls, 10-19.

Sakai, T., 1961. New species of Japanese crabs from the collection of Ilis Majesty the Emperor of Japan. Crustaceana, 3:131-150, pls. 2, 3.

Sakai, T., 1965. The crabs of Sagami Bay. Tokyo, i-xvi, 1-206, 1-92, 1-32, pls. 1-100.

Serène, R., 1954. Sur quelques espèces rares de brachyures (Leucosidae) du l'indopacifique. Treubia, $22: 453-499$, pls. 7-10.

Serène, R., 1955. Ditto. 2è Partie. Ibid., 23: 137-218, pls, 6-11.

Serène, R. and K. Romimohtarto, 1969. Observations on the species of Dorippe 
from the Indo-Malayan region. Mar. Res. Indonesia, 9: 1-35.

Shen, C. J., 1931. The crabs of Hong Kong. Part II. Hong Kong Nat., 2: 185-197, pls. 12-14.

Shen; C. J., 1932. The brachyuran Crustacea of North China. Zool. Sinica, ser. $\Lambda$, $9: 1-320$, pls. $1-10$.

Stebbing, T. R. R., 1920. South African Crustacea (Part X of S. $\Lambda$. Crustacea, for the marine investigations in South $\Lambda$ frica). Ann. S. $\Lambda$ fr. Mus., 17: 231-272, pls. 18-27 (Crust., pls. 98-107).

Stebbing, T. R. R., Ditto (Part XI of S. A. Crustacea, for the marine investigations of South Africa). Ibid., 18: 453-468, pls. 13-20 (Crust., pls. 108-115).

Stephensen, K., 1945. The Brachyura of the Iranian Gulf. Danish Sci. Invest. Iran, 4: 57-237.

Stimpson, W., 1858. Prodromus descriptionis animalium evertebratorum, quae in Expeditione ad Oceanum Pacificum Septentrionalem, a Republica Federata missa, Cadwaladaro Ringgold et Johanne Rodgers Ducibus, observavit et descripsit. Pars VII. Crustacea Anomoura. Proc. Acad. nat. Sci. Philad., 10 : 225-252 (63-90).

Stimpson, W., 1907. Report on the Crustacea (Brachyura and Anomura) collected by the North Pacific Exploring Expedition 1853-1856. Smiths. misc. Coll., 49: 1-240, pls. 1-26.

Terazaki, T., 1902. "Nippon Kanirui Tsusetsu" [A general view of Japanese crabs]. No. 6. Dobutsu-gaku Zasshi [Zool. Mag.], 14: 213-221 (in Japanese).

Tyndale-Biscoe, M. and R. W. George, 1962. The Oxystomata and Gymnopleura (Crustacea, Brachyura) of Western Australia with descriptions of two new species from Westen Australia and one from India. J. Roy. Soc. W. Aust., 45-96.

Walker, $\Lambda$. O., 1887. Notes on a collection of Crustacea from Singapore. J. Linn. Soc, London, Zool., 20 : 107-117, pls, 6-9.

White, A., 1847. List of the specimens of Crustacea in the collection of the British Museum. London, i-viii, 1-143.

White, A., 1847a. Short descriptions of new or little-known decapod Crustacea. Proc. zool. Soc. London, 15 : 221-228.

White, A., 1848. Ditto. Ann. Mag. nat. Hist., ser, 2, $2: 282-288$.

Whitelegge, T., 1900. Crustacea. Part I. Scientific results of the trawling expedition of H.M.C.S. "Thetis," off the coast of New South Wales, in February and March, 1898. Mem. Aust. Mus., 4 : 135-199, pls. 32-35.

Yokoya, Y., 1933. On the distribution of decapod crustaceans inhabiting the continental shelf around Japan, chiefly based upon the materials collected by S.S. Sôyò-Maru, during the year 1923-1930. J. Coll. Agr. Tokyo Imp. Univ., 12: $1-226$. 


\section{Explanation of Plate 1}

Figs. $\Lambda, B$. Petalomera yamashitai sp. nov.

A, holotype, ovig. 우, $9.5 \times 9.6 \mathrm{~mm}$.

B, paratype, ovig. ㅇ, $9.6 \times 9.5 \mathrm{~mm}$.

Figs. C, D. Nursia rhomboidalis (Miers).

C, ơ, $11.4 \times 14.2 \mathrm{~mm}$.

D, ふ̄, $12.8 \times 16.7 \mathrm{~mm}$. 

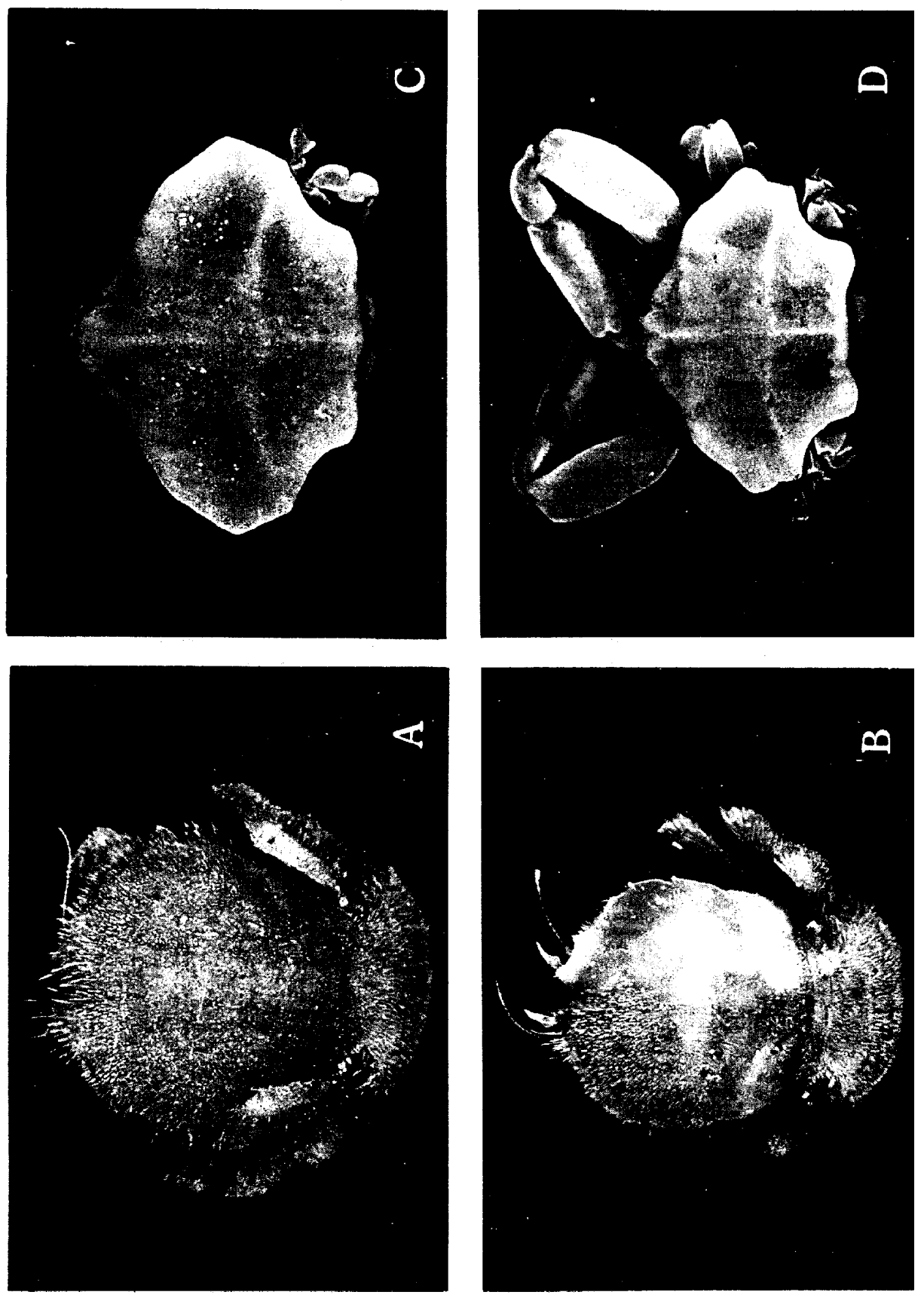